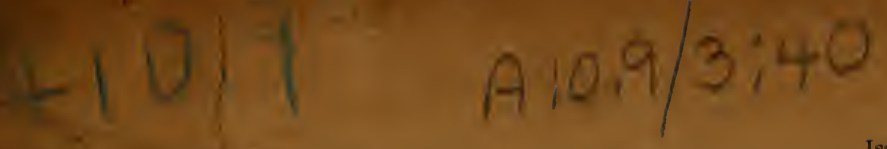

Issued August 26, 1915.

HAWAII AGRICULTURAL EXPERIMENT STATION,

J. M. WESTGATE, Agronomist in Charge.

Bulletin No. 40 .

\title{
THE SOILS OF THE HAWAIIAN ISLANDS.
}

BY

W. P. KELLEY,

Chemist,

AND

WM. MoGEORGE

AND

ALICE R. THOMPSON, Assistant Chemista. DOCYOFFFL

$\approx$

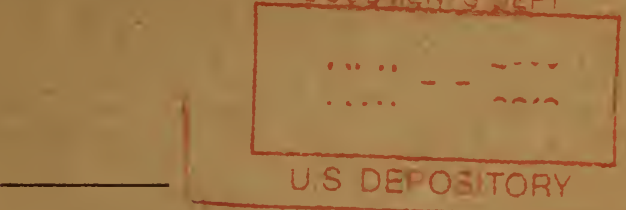

UXDER THE SUPERVISION OF

STATES RELATIONS SERVICE,

ऍ. S. DEPARTMENT OF AGRICULTURE. 



\title{
HAWAII AGRICULTURAL EXPERIMENT STATION,
}

J. M. WESTGATE, Agronomist in Charge.

Bulletin No. 40.

\section{THE SOILS OF THE HAWAIIAN ISLANDS.}

\author{
BY \\ W. P. KELLEY, \\ Chemist, \\ AND \\ WM. McGEORGE \\ AND \\ ALICE R. THOMPSON, \\ Assistant Chemists.
}

UNDER THE SUPERVISION OF

STATES RELATIONS SERVICE,

t. S. DEPARTMENT OF AGRICULTURE.

WASHINGTON:

GOVERNMENT PRINTING OFFIOE.

1915. 


\section{HAWAII AGRICULTURAL EXPERIMENT STATION, HONOLULU.}

[Under the supervision of A. C. TrUE, Director of the States Relations Service, United States Department of Agriculture.]

Walter H. Evans, Chief of Division of Insular Stations, States Relations Service. STATION STAFF.

J. M. Westgate, Agronomist in Charge.

J. Edgar Higgins, Horticulturist.

W. P. Kelley, ${ }^{1}$ Chemist.

D. T. Fullaway, Entomologist.

WM. McGeorge, Chemist.

F. G. Krauss, Superintendent of Extension Work.

Alice R. Thompson, Assistant Chemist.

V. S. Holt, Assistant Horticulturist.

C. A. SAHR, Assistant in Agronomy.

F. A. Clowes, Superintendent Hawaii Substations. 


\section{LETTER OF TRANSMITTAL.}

Hoxolulu, Hawair, September 29, 1914.

SIR: I have the honor to submit herewith and recommend for publication as Bulletin No. 40 of the Hawaii Experiment Station a paper on The Soils of the Hawaiian Islands, by W. P. Kelley, chemist, and William McGeorge and Alice R. Thompson, assistant chemists. The soil inrestigations of the station for the past six years hare greatly helped in elucidating Hawaiian soil problems. In the present bulletin the practical bearings of these scientific investigations are pointed out.

Respectfully,

Dr. A. C. TRue,

E. V. Wilcox, Special Agent in Charge.

Director, Office of Experiment Stations,

U.S. Department of Agriculture, Washington, D. C.

Publication recommended.

A. C. True, Director.

Publication authorized.

D. F. Houstox, Secretary of Agriculture. 


\section{CONTENTS.}

Introduction Page.

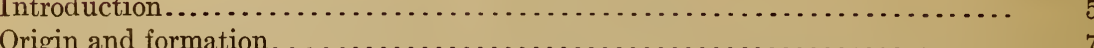

Physical properties

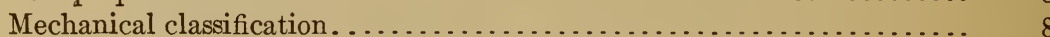

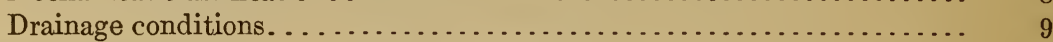

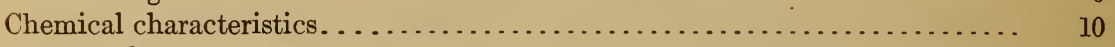

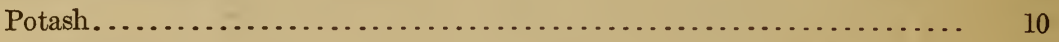

Phosphoric acid......................................... 11

Nitrogen........................................... 11

Peculiar soils........................................... 12

Coral sand soils........................................... 13

Lime-magnesia ratio.................................... 13

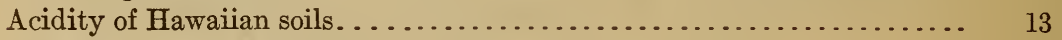

Ferrous iron............................................. 14

Biological conditions........................................ 14

Nitrification......................................... 14

Ammonification........................................ 15

Soil management.......................................... 15

Tillage.................................................. 15

Injurious effect of puddling. .............................. 16

Rotation of crops............................................... 17

Erosion and drainage....................................... 18

Use of fertilizers....................................... 18

Chemical and mechanical composition of some Hawaiian soils............ 19 


\section{THE SOILS OF THE HAWAIIAN ISLANDS.}

\section{INTRODUCTION.}

The purpose of this bulletin is to discuss briefly the general properties of the soils of the Hawaiian Islands and to point out the practical bearings of the investigations ${ }^{1}$ that have been made on them. For about six year's the writers have been investigating these soils. One phase of this work has been in the nature of a soil survey. In this connection a large number of samples have been collected and a number of unusual peculiarities and soil types have been observed. Soon after beginning this work it became apparent that the main body of Hawaiian soils had not been scientifically investigated. Considerable study had been previously devoted to the soils of Hawaii, but always with reference to special localities or industries. Maxwell's ${ }^{2}$ discussion is based on analyses of samples drawn from the lands devoted to sugar cane and his use of the terms "uplands" and "lowlands" refers to the humid and arid, or upper and lower portions, respectively, of the sugar belt. However, only about 250,000 acres lying along the shore line, out of a total area of over $4,000,000$ acres, are cultivated in this crop. The investigations upon which this bulletin is based were made principally on the upland soils above the sugar belt.

Almost the entire surface of Hawaii is characterized by a rolling topography. The elevation increases everywhere in passing inland from the sea, the grade varying in different localities. Each island contains one or more mountains or mountain ranges and usually with numerous spurs and sharp ridges projecting toward the sea. In almost every section the arable land is broken up by gulches or deep ravines, which now form natural watercourses, the beds of some of which have been worn to great depths. This has brought about the loss of a great amount of tillable land and adds greatly to the cost of farm operations. The tillable lands generally occur in comparatively narrow strips of irregular size and shape between gulches and extend from the sea toward the mountains.

It is difficult to estimate the area of arable land, only a small percentage of which has yet been brought under cultivation. The main portion is now being used for pasture in much the same way as in the great range sections of the mainland. The rainfall varies

1 See Hawaii Sta. Buls. 26, 28, 30, 31, 33, 35, 37, and 38.

2 Lavas and Soils of the Hawaiian Islands. Honolulu, 189x. 
between wide extremes; in some localities semiarid or even arid conditions prevail, but over a large part of the uplands the rainfall is sufficient for a great variety of crops. In portions of the windward side of Maui and Hawaii, i. e., the side first reached by the northeast trade winds, the rainfall is very heavy. Until recently the main portion of the upland on account of its inadaptability to sugar was thought to be unsuited to cultivated crops. Slowly, however, it is being brought under cultivation and with the advent of a more numerous small farming class it is likely that practically all of the tillable lands of the islands will be utilized for cultivated crops. There are no valid reasons why general farming could not be practiced on these lands. The soils are rich and adapted to a wide range of crops. In the more arid sections the application of the principles of dry-land farming will doubtless insure the success of many crops. The increasing demands for land for cultivation in recent years have brought to the station many requests for information regarding the soils. A part of this information it is hoped will be supplied by this bulletin.

It should be understood from the outset that the methods of classification and mapping usually employed in soil surveys are not adapted to Hawaiian conditions and that nothing less than a systematic sampling of almost every acre will suffice to give an accurate idea of the location of all soil types. This is especially true of Oahu, where both the chemical and physical composition vary greatly in passing over short distances. For this reason no attempt to map the soil areas will be made. Furthermore, the peculiar properties of Hawaiian soils are such as to render the use of terms employed in the description of soil types elsewhere of doubtful application. In some instances the common systems of classification have been used, however, but the reader is cautioned against too strict interpretation of these terms.

The term "clay" especially requires definition. In the Tropics, where the soils have been formed from the disintegration of basaltic lava, the so-called clay is usually not composed of aluminum silicate, and its properties sometimes differ greatly from true clay. The soils of Hawaii, although usually very heavy in charaoter and frequently containing as much as 50 per cent by weight of particles as fine as clay, are not clay soils in the true sense. They are characterized by a high content of iron and aluminum hydrates and low silica content. Such soils are designated as laterites, and recently the process leading to their formation has been designated as lateritization, in contradistinction to the term "kaolinization," used in reference to clay formation. The clay seems to be composed mainly of iron and aluminum hydrates and a double silicate of iron and alumina. 
There are also some very unusual types of soil in the islands. On Oahu highly manganiferous and titaniferous soils occur, the former sometimes containing almost 10 per cent manganese oxid and the latter as high as 35 per cent titanium dioxid $\left(\mathrm{TiO}_{2}\right)$. No such soils are known to occur in any other country of the world.

\section{ORIGIN AND FORMATION.}

The soils of the Hawaiian Islands, with the exception of small areas near the sea, have been formed from the disintegration products of basaltic lava. The lava is composed mainly of pyroxenes, amphiboles, and soda-lime feldspars, with small amounts of magnetic oxid of iron. They are, therefore, highly ferruginous and basic. At the time of flow, and possibly to some extent afterwards, the vapors of burning sulphur act on the lava with the consequent formation of sulphates. The frequent occurrence of gypsum is traceable to this cause. The most important disintegrating agent is weathering. One of the first changes which takes place in the lava is that of oxidation. The iron in the original lava occurs mainly in the ferrous state, but upon exposure to the air the normal gray color quickly changes to red or yellow, due to the oxidation and subsequent hydration of the iron. Coincident with oxidation leaching takes place. The lime, magnesia, and soda to a large extent, and potash to lesser degree, are leached out by rain waters as silicates and carbonates, leaving behind a residue rich in iron and alumina, but much reduced in silica content.

The normal lavas from the main craters seem to be quite uniform in composition, while the flows from the secondary craters vary in composition, due perhaps to mixing with weathered and partially decomposed material near the surface. As oxidation proceeds, the surface of the lava crumbles away, thus allowing rain waters free access to the interior, and consequently greatly increasing the rate of solution. Another potent agent in the formation of soils is the growth and subsequent decay of plant roots. Within an incredibly short time after a lava flow plant life gains a foothold, which, aided by the solvent and oxidative effects naturally going on, soon pushes its roots into cracks and crevices. The carbonic acid given off by the roots aids in the decomposition, and the excessive heat of the tropical sun considerably hastens the solutions and oxidations going on. In general, soil formation is extremely rapid in the islands.

Much of the soil at the lower elevations has been formed by sedimentation and erosion from higher elevations. In fact there is much evidence that these processes account mainly for the location and formation of the sporadic types of manganiferous and titaniferous soils of Oahu. In many places, however, the soils are residual, with only slight transportation of soil material at most. In many sections 
the disintegration has been so complete that scarcely a trace of unaltered lava can be detected in the soil.

The soils range from 6 inches to many feet in depth. After a few years of cultivation but little demarcation between the soil and the subsoil is left, except in locations of heary rainfall. The humus content in passing downward decreases slowly, but the fertility in the drier sections is not greatly different for many feet below the surface. Where the drainage and aeration conditions are suitable, plant roots penetrate to great depths, and there is every indication that the plant food is as available several feet below as on the surface. No injurious effects, such as commonly follow the turning up of inert subsoil, are produced in the drier sections by plowing to the depth of 30 inches.

\section{PHYSICAL PROPERTIES.}

It is recognized that the physical properties of Hawaiian soils demand far more attention than usual; and it seems that purely physical factors within the control of the farmer are probably more important than the chemistry involved. The difficulties met with in the maintenance of suitable tilth, the rapidity with which the soil becomes closely compacted following rains, the lack of drainage and aeration, and the striking effects of green manuring and soil burning are all probably explainable in large part on physical grounds.

\section{MECHANICAL CLASSIFICATION.}

No attempt will be made to classify completely the soils of every section; in general, however, they may be divided into clay, silt, sandy, and humus soils. The clay type is the most abundant and in some instances contains unusually large amounts of clay, ranging as high as 50 per cent. The upland soils of Oahu, with the exception of the manganiferous and titaniferous areas, belong to the heary clay type. The subsoils usually contain still more clay. In these sections practically no sand or gravel occurs, and the humus content is comparatively low. The soils of windward Oahu contain somewhat less clay than the above and more silt and gravel, and are consequently less difficult to till, but the subsoils contain higher percentages of clay and much less organic matter than the surface soils. The manganiferous and titaniferous soils, above referred to, are silty in character, while small areas of arable land in some localities around the coast on the leeward side of Oahu resemble adobe.

The Haiku district of Maui is composed largely of clay and clay loam soils with somewhat more humus than on Oahu. The Kula district is characterized by a light silty soil of high humus content which is several feet deep in some places. The Nahiku soils are high in humus and contain much stone and gravel. The soils of 
west Maui, particularly the land of the Honolua Ranch Co., belong: to the clay type.

On the island of Hawaii great diversity of soil types occur, and only the most general statements can be made at the present time. In the Olaa district, where the precipitation is very heary, the soils contain a large amount of partially decomposed organic matter and are sandy or gravelly in texture. Along the Hamakua coast above the sugar belt a comparatively high percentage of clay occurs in some places; in others the soil has a high humus content. The soils of the Kohala district are clay loams, shading off to the west into silty loams. There is a large body of a deep, loose, silty soil, high in humus in this district that is now occupied by the Parker Ranch Co. In the Kona section the soils rary enormously. In places the virgin fern soils contain unusually high percentages of humus and, generally speaking, more or less stones and gravel.

The soils of Kauai, that have been most thoroughly investigated, were from Kapaa and the McBryde homesteads. The Kapaa lands contain high percentages of clay and are liberally supplied with humus; sometimes they resemble adobe. The McBryde homestead section is composed principally of clay loams. An insufficient number of samples have been examined from the other sections of the islands to justify any generalization. The table of mechanical analyses at the end of the bulletin will give some idea of the physical composition of representative samples from different districts.

\section{DRAINAGE CONDITIONS.}

Proper drainage is one of the greatest necessities in Hawaiian soil management. The rainfall in some sections is heary throughout the year, and in almost all sections heavy rains sometimes occur. It is of the greatest importance that the excessive rains be able to drain away without eroding the surface into gullies or flowing over it, for in the latter event great injury will result from puddling the clay and shutting the air away from the roots of plants. Unless proper drainage be provided, suitable conditions of aeration in times of wet weather will be impossible. One of the most perplexing questions that the pineapple growers have had to contend with is that of drainage, and as yet no thoroughly satisfactory method has been devised. Generally the open-ditch system prevails. Drainage is naturally most difficult in heavy clay soils such as predominate in the pineapple sections.

The application of lime for the purpose of ameliorating the heary clays seems to be of doubtful effect. In some instances lime fails to cause granulation such as takes place in normal clays. The clay is present in a state of such fine division as to be colloidal and has the power of imbibing large amounts of water. When wet the iron and

$98554^{\circ}-$ Bull. $40-15-2$ 
alumina become partially hydrated, and the soil mass swells considerably, thereby effectively closing the pores. Upon drying out contraction takes place, which results in the formation of large cracks. Thus the roots are injured and a condition provided for rapid evaporation of the soil moisture. This can be prevented only by increasing the humus and maintaining a mulch on the surface. It is evident from the above that a condition of insufficient aeration prevails in the clay soils during times of wet weather, and in fact anaerobic conditions of ten prevail.

Investigations on the physical properties of Hawaiian soils show that fertilizers exert considerable physical effect. Phosphates materially retard the movement of moisture in the heavy clays, while nitrate of soda produces similar effects in some of the highly organic soils. A number of fertilizing substances cause a deflocculation of the clay. It has been found, on the other hand, that heat causes the clay to become granulated and, therefore, is a means of increasing aeration and drainage.

The predominant color of Hawaiian soils is red, due to iron which is present in large amounts. Various shades of red often occur close together. There are also considerable areas of yellow soil. These colors seem to be referable to the state of hydration of the iron. The dark red color which predominates in the more arid sections is probably due to amorphous hematite and the yellow color to limonite. In the humid sections, where the humus content is not high, the color of the soil is generally lighter, due to the iron being in the ferrous form. The iron is generally so abundant and completely disseminated in the soil as to obscure the humus unless present in large amounts.

\section{CHEMICAL CHARACTERISTICS.}

Soils naturally partake to a considerable extent of the nature of the minerals from which they have been derived, and, since Hawaiian soils have been formed from basaltic lava, they are potentially basic. This does not mean, however, that in all cases the soils are free from acidity, as will be pointed out later. In general Hawaiian soils contain unusually high percentages of iron and alumina, the former sometimes exceeding 50 per cent by weight. The silica content is low as compared with mainland soils. Lime and magnesia are present in quite variable amounts, but usually more abundantly than in nonlimestone countries.

\section{POTASH.}

The potash content on the whole is rather below the average, but frequently it is relatively more soluble than usual and consequently more available. It is also more constant in different sections of the islands than any other of the so-called plant-food constituents. 
Phosphoric acid is comparatively abundant, but there is a wide range of variation in the percentages present. The upland soils of Oahu generally, but not always, contain less phosphoric acid than any other extensive body of arable land in the islands. The soils of windward Oahu, with the exception of the lowlands devoted to rice, also usually contain small percentages of phosphoric acid. The Kula soils are rich in phosphoric acid, the Haiku soils intermediate, while in the Nahiku section of Maui the content is variable. The soils of Kohala on Hawaii are unusually rich in phosphoric acid. It must not be understood that the above statements apply universally to a given section for there is often great variation in comparatively short distances.

Notwithstanding the high percentages of phosphoric acid in many Hawaiian soils the availability is, on the whole, rather low, and phosphate fertilization is necessary in most instances except where the humus content is high. The low availability of the phosphoric acid is probably due to its being chemically combined with iron and aluminum in difficultly soluble combinations. Hawaiian soils have the power of fixing enormous amounts of soluble phosphates. Experiments have demonstrated that the red clay type of soil can fix more than 4 per cent of its weight of phosphoric acid. There is, therefore, very little danger of loss of phosphoric acid by leaching. On the other hand, it is also necessary to thoroughly mix phosphate fertilizers with the soil in order that the distribution of roots may not be too near the surface. Experiments seem to indicate that various phosphates continue to be available for a considerable time after having been applied, notwithstanding the fact that the phosphoric acid is insoluble in water. Decaying organic matter exercises a very marked effect on the availability of phosphates, and even insoluble forms may be made available by plowing under green manure.

\section{NITROGEN.}

As stated above, the humus content is high as compared with mainland soils, and consequently the nitrogen is also high, but its availability is low, due to poor aeration. The soils of Kula, Nahiku, Olaa, and parts of Kohala and Kona on Hawaii are generally very rich in nitrogen. Table II shows the percentages of humus and nitrogen in representative samples from these districts.

On account of there being a high percentage of nitrogen present, it is desirable to increase its availability whenever possible. This can best be done by increasing the aeration, thereby improving the conditions for bacterial action which decomposes the organic nitrogen into available forms. It has been found, however, that heating soil 
greatly increases the ammonia content and is a means of making available a considerable portion of the nitrogen, but it should be remembered that in so doing considerable loss of nitrogen takes place through the destructive effect of the heat.

\section{PECULIAR SOILS.}

One of the peculiarities of Hawaiian soils is the unusually high content of some of the rarer elements, notably manganese and titanium, which are supposed not to be necessary for plant growth. The manganiferous soils, with relatively unimportant exceptions, are located only on Oahu between the Koolau and Waianae Mountains, but it is not possible to give an accurate estimate of the extent of this type or to trace its location in detail. In general, it may be said to occur most abundantly toward the lower levels between the mountain ranges, in pockets or level stretches that receive the drainage and wash from higher levels. This type of soil occurs most abundantly in the Waipio, Wahiawa, and Halemanu districts, but may also be found in portions of Waialua, Waimea, and in the upper part of the Oahu Sugar Co.'s land. There are also small areas of highly manganiferous soil near Haiku on Maui, Homestead on Kauai, and in the Palawai Basin of Lanai.

Sometimes the manganese areas are small, while in other places as much as 20 or more acres may occur in one body. The percentage of manganese varies greatly. A few tenths of 1 per cent occur in nearly all Hawaiian soils. The manganiferous soils, however, often contain more than 5 per cent, expressed as manganese oxid $\left(\mathrm{Mn}_{3} \mathrm{O}_{4}\right)$. These soils are characterized by a dark color, sometimes almost black, due to the presence of manganese dioxid, and have a silty texture in contrast to the heavy clay character of the surrounding soils. Generally concretions composed of manganese dioxid can be found mixed with the soil and more abundantly in the subsoil. The manganese is nearly always more abundant in the soil than in the subsoil. In some places where the surface soil contains more than 4 per cent the subsoil contains less than 1 per cent. A high manganese content is quite injurious to pineapples, causing the leaves to become yellow and lowering the quality of the fruit. Some other crops are also injuriously affected, but sugar cane, sisal, cabbage, turnips, and some other crops seem to be unaffected.

As in the case of the manganiferous soils, it is not possible to locate definitely all of the highly titaniferous areas. All Hawaiian soils contain comparatively high percentages of titanium. The soils of the Kunia section, however, are unusually high in titanium, containing in some instances as much as 35 per cent titanium dioxid $\left(\mathrm{TiO}_{2}\right)$, but the titanium is relatively insoluble, and consequently the usual agricultural analysis fails to show the total amount present. 
It seems that titanium is inert toward plant growth. It is extremely insoluble and occurs to some extent as small fragments of a black mineral, possibly ilmenite. Generally speaking, the titanium soils are silty, but sometimes they have a very fine texture. In a few places in the upper portion of the Wahiawa district, Opaeula and Kunia on Oahu, and near Pogue's station on Maui it occurs in the form of a blue gray layer composed of very fine particles which soil the fingers very much like charcoal. Sometimes a high percentage of ferrous iron is associated with the titanium. If phosphoric acid should become chemically combined with the titanium, the insoluble nature of this compound would render it unavailable to plants.

CORAL SAND SOILS.

These soils are of relatively small importance and are located near the sea level. Such soils, as the name indicates, have been formed mainly from grains of coral sand, which are composed chiefly of calcium carbonate. After the sand banks have been built up above sea level, organic matter and small amounts of soil gradually become incorporated with them, and certain plants soon gain a foothold, resulting in the formation of humus and later in a fairly fertile soil. An important use to which the coral beds and sand banks are being put is as a source of lime which is recommended for use where liming is needed.

LIME-MAGNESIA RATIO.

Hawaiian lava contains considerably more lime than magnesia, but frequently the opposite is the case with the soil. Generally speaking, the soils formed from black sand contain much higher percentages of magnesia than lime. Therefore, the lime-magnesia ratio is abnormal. So far as is now known, however, no injurious effects are produced on crops. Experiments carried out with the object of modifying the ratio of lime to magnesia have not indicated any practical advantage to be derived in this way. The lime is much more soluble than the magnesia, even where the magnesia content greatly exceeds that of lime.

\section{ACIDITY OF HAWAIIAN SOILS.}

Notwithstanding the highly basic character of Hawaiian soils, they generally give an acid reaction toward litmus. The acidity, as determined by the Vietch method, sometimes indicates the need of large amounts of lime. In harmony with this is the very low content of carbonate except where coral sand is present. The soils around Honolulu, for example, contain not more than 0.1 per cent carbon dioxid $\left(\mathrm{CO}_{2}\right)$, although the lime and magnesia are high. It has been supposed that the sod lands are generally acid, but it seems that the slow growth of crops is due more to the lack of aeration than the presence of actual acidity. Lime has been used to considerable 
extent on the sugar lands with good effects, but in many instances negative results have been obtained by the pineapple growers. Where liming is to be practiced, coral sand is recommended.

With the exception of phosphoric acid, all the mineral elements of plant food in Hawaiian soils are soluble in water to a considerable extent, and if suitable physical conditions be maintained, and the humus content kept up, the need for mineral fertilizers will be greatly reduced. The solubility of the mineral constituents can also be considerably increased by soil heating, which probably is a factor in the more vigorous growth of crops noticed where refuse had been burned.

\section{FERROUS IRON.}

Soluble ferrous iron is considered to be toxic to plants, but the amount of water soluble ferrous iron in Hawaiian soils is extremely small, except where there is insufficient aeration. Poor drainage and an excess of water in soils prevents the circulation of air, and such conditions are favorable for the formation of soluble ferrous iron. The injurious effects on crops attending heavy rains may be due to some extent to the formation of ferrous compounds. The high iron content of Hawaiian soils is composed in part of insoluble ferrous oxid, but the imperfections in analytical methods do not permit of its accurate determination. Consequently the percentages of ferrous iron are not given in the tables of analysis.

\section{BIOLOGICAL CONDITIONS.}

The availability of nitrogen in soils depends on the activity of bacteria and fungi. There are many factors that influence their activity, one of the most important of which is the state of aeration. In general the aeration of Hawaiian soils is not sufficient for the best development of beneficial bacteria. Consequently the nitrogen does not become available fast enough for maximum growth of crops.

\section{NITRIFICATION.}

Nitrification in soils requires the free movement of air, and the more restricted the circulation of air the less actively are nitrates formed. This is strikingly illustrated by contrasting nitrification in the silty soils of Kula and the Parker ranch, where active nitrification takes place, with that of the heary clay types common in other parts of the islands. In the rice soils nitrification is suspended and the clay soils frequently contain almost no nitrate. The inertness often observed in newly plowed sod lands is due in part to the lack of nitrification. It follows, then, that any treatment which increases soil aeration also stimulates nitrification. As pointed out above, aeration may be increased by increasing the humus content, and probabiy one of the most important reasons for the beneficial 
effects of green manuring is that it stimulates bacterial action. It is commonly believed that the presence of carbonate of lime is essential for nitrification, through the maintenance of neutral conditions, but it seems that when other conditions are suitable, active nitrification takes place in Hawaiian soils which contain unusually small amounts of lime. The results of our experiments indicate that the iron and alumina present may partially take the place of lime in maintaining the necessary neutral condition. On the other hand, experiments show that magnesium carbonate seems to be distinctly detrimental to nitrification, while the magnesia naturally present in the soils does not seem to interfere. While nitrate is probably the most available form of nitrogen, ammonia is also available for certain crops.

\section{AMMONIFICATION.}

Ammonification is more active in Hawaiian soils than nitrification, and investigations show that aeration is not as essential to this process as it is to nitrification. Aeration, however, also stimulates ammonification. During the several months, in which new lands are usually cultivated previous to planting, ammonification and nitrification are each stimulated to a considerable extent, but in many localities only very small amounts of nitrate are found. In such instances plants seem to absorb the nitrogen most largely in the form of ammonia. In the case of aquatic plants ammonia is preferable to nitrates. Soil heating stimulates the formation of ammonia, both as a direct result of the heat on the organic nitrogen and probably indirectly, by increasing the activity of bacteria. It has also been found that the application of lime stimulates the formation of ammonia, and magnesium carbonate produces still greater stimulation. The effects of magnesium carbonate on ammonification are therefore the opposite of those on nitrification.

All Hawaiian soils seem to be abundantly supplied with bacteria, and the wide distribution and vigorous growth of a great variety of leguminous plants indicate that the tubercle-forming organisms are abundantly distributed. In fact, nodules occur on the roots of many leguminous plants in the islands. Up to the present time very little use has been made of artificial inoculation, and it is of doubtful importance.

SOIL MANAGEMENT.

TILLAGE.

A part of the high cost of tillage in Hawaii is traceable to the unusual properties of the soil. The clay when wet is extremely sticky and, even when the moisture content is low, it adheres tenaciously to the plow, thus materially increasing the draft. Frequent deep 
plowing, however, is a necessity. The subsoil, upon standing, becomes closely compacted, and heavy rains and walking over the surface greatly increase this tendency. Consequently it is necessary to replow at frequent intervals. In many localities the aeration is restricted to a layer a few inches in depth near the surface and nitrification scarcely ever becomes active. Deep plowing will permit the absorption of a much larger percentage of heavy rains, thus greatly reducing erosion and storing up much larger amounts of moisture for drier seasons. Most of the soils that are cultivated in pineapples become hard and closely compacted within a few months after planting. Consequently it is necessary to plow as deeply as possible between crops.

Subsoiling has not been extensively practiced, but deep plowing should be the rule in all sections. The subsoils are not very different from the soils, except in some of the rainy sections like Olaa, and, after being acted upon for a short time by weathering influences, seem to be equally as fertile as the surface soil. In the drier sections deep plowing encourages deeper root development, thus tending to enable the crop to withstand drought. Successful soil management in Hawaii, therefore, requires deep plowing, followed by frequent shallow cultivation.

\section{INJURIOUS EFFECT OF PUDDLING.}

Great care and intelligence must always be exercised in plowing and tilling clay soils. The clay particles are extremely small and tend to settle down between the coarser grains, thus clogging the pores. However, the fine particles can be made to unite into granules by the judicious handling of the soil. In the natural state carbonic acid formed from the decomposition of regetation and aided by evaporation causes the smaller particles to coalesce into granules, which then act as if the particles themselves were coarse. In this condition a heavy clay soil may be well aerated and fertile. On the other hand, tillage, in times of too great moisture, breaks up the granules, producing a puddled condition which is very difficult to bring back into a state of granulation.

During the early stages of the cultivation of sod lands the bacterial processes bring about a rapid decomposition of the vegetable matter, which causes the clay to become granulated. After a few years, however, the organic matter has been so completely decomposed that the clay is easily puddled under the ordinary operations of cultivation. A single cultivation of such soils when they are wet causes serious puddling. The pineapple growers in the Wahiawa district have greatly injured their lands by cultivating too soon after rains. Much of the so-called exhaustion of Hawaiian pineapple soils is traceable to wet cultivation. 


\section{ROTATION OF CROPS.}

The rotation of crops is essential to a permanent upkeep of the soil. It is not necessary to enumerate the reasons for this fact. Some of them still remain in obscurity. Crop rotation is of very great importance in the proper management of Hawaiian clay soils. As stated above, the humus is considerably above the average, but the peculiarities of the clay necessitate still greater amounts. The fine particles of iron and alumina become hydrated when wet and adhere to all the soil particles. Only by the maintenance of large amounts of humus can such soils be kept in a suitable condition for plant growth.

The pineapple growers, following the lead of the sugar planters, have attempted to grow the same crop continuously, but in many cases with poor results. The reason is found in the need for humus. Crop rotation will supply this need, if a green manuring crop be plowed under. Humus is the key to successful soil management in Hawaii as is the case elsewhere. At the present time this fact is being recognized by the sugar planters as never before. Instead of burning the trash and crop residue, they should be plowed under, thereby increasing the humus content. Organic matter undergoes rapid decomposition in the Tropics, and the necessary condition of aeration hastens the decomposition. It is necessary, therefore, to plow under green manure frequently. The details of crop rotation will not be discussed in this bulletin. With the pineapple lands a green manuring crop can be grown between crops. The choice of the green manuring crop will depend on the locality. It should be a legume if possible. The single-crop system can not be permanent, and it is of doubtful economy at any time. Sooner or later it must inevitably give way to diversification.

The retention of moisture during dry weather can be greatly increased by increasing the humus content of the soil, so that sufficient moisture will be retained for the growth of crops during continued dry weather. The success of crops in the semiarid sections of Kula and the Parker ranch is due very largely to the high humus content of the soils. On one of the fields at the experiment station, where a legume has been plowed under each year for the past several years, the structure of the soil has been materially modified and the moisture-retaining power greatly increased. Similar effects can be had with any of the clay soils throughout the islands. Hawaiian clay soils require a higher percentage of moisture than is usual, due to their high hygroscopic capacity and the slow morement of moisture through the soil. Hygroscopic moisture will not sustain plant life.

$98554^{\circ}-$ Bull. $40-15-3$ 
EROSION AND DRAINAGE.

The amount and extent of soil erosion in Hawaii can hardly be overestimated. The heavy rains wash away enormous quantities of soil. This can be prevented by a combination of deep plowing, proper drainage, and green manuring. When the soil is compacted rain waters flow over the surface rather than being absorbed, thus washing away much soil material and cutting gullies. Where ditches are provided they should be arranged close together in the direction of the greatest fall, so as to carry away the surplus water and prevent overflow. In some places much damage has been done to crops by the overflow from inadequate ditches. The use of dynamite, for the purpose of shattering the subsoil and allowing better drainage, has been practiced with good results in some localities. The plowing under of coral sand has also been effectively used in some localities as a means of improving aeration and drainage conditions, and around Honolulu gardeners frequently mix black sand with the soil for the same purpose.

\section{USE OF FERTILIZERS.}

The table of chemical analyses at the end of the bulletin shows that, on the whole, Hawaiian soils are well supplied with phosphoric acid and nitrogen with a medium content of potash. In many localities the soil contains unusually high percentages of phosphoric acid and nitrogen. Nevertheless, heavy fertilization is generally practiced, due to the low availability of plant food. It is more rational, however, to make available the plant food already contained in the soil, if this can be done economically. The methods by which this may be accomplished have already been suggested. These consist briefly in increasing the aeration by deep plowing, thorough drainage, and the frequent plowing under of green manures, which, if carried out systematically, will materially lessen the need for commercial fertilizers.

The exact fertilizer for each crop varies in different districts. In general both nitrogen and phosphoric acid give good results. Nitrate of soda, ammonium sulphate, and organic forms of nitrogen each produce good effects, but, generally speaking, organic forms and ammonium sulphate are recommended in preference to nitrate of soda, especially during seasons of heavy rainfall. The soils have the power of absorbing large amounts of ammonium sulphate, thus preventing its being leached out, but nitrate of soda is not fixed by soils.

When the organic matter is deficient the phosphoric acid is generally of low availability and phosphate fertilizers are needed. Soluble phosphates will give best immediate returns, but if applied in conjunction with decaying organic matter, insoluble forms may be used. Pot experiments at the station, carried through several crops, indi- 
cate that rock phosphate, when acted upon for a few months by decaying organic matter, becomes as available as superphosphate, but when applied without organic matter the immediate effect is negligible. From these experiments it also seems that water-soluble phosphates produce better immediate effects than reverted phosphate and bone meal. It has also been found that the availability of the phosphate already in the soil can be considerably increased by plowing under green manure, and that liming in some instances is necessary before phosphate fertilizer will give its best effects. Hawaiian soils have the power of fixing very large amounts of phosphoric acid, and, therefore, loss will not be sustained by leaching. It seems, however, that where excessive amounts have been applied some of the phosphoric acid becomes reverted into unavailable forms.

When potash fertilizer is needed the sulphate is recommended, and potash, like ammonia, is not lost by leaching if applied in reasonable amounts.

\section{CHEMICAL AND MECHANICAL COMPOSITION OF SOME HAWAIIAN SOILS.}

In the following tables are given the results of chemical and mechanical analyses of a large number of soils and subsoils taken from different parts of all of the principal islands. In Table I the results of the chemical analyses of soils and subsoils ${ }^{1}$ are given; in Table II the humus, humus ash, and total nitrogen are stated; and in Table III the mechanical composition is shown. In general the soil represents the first foot and the subsoil the second foot taken. In most instances the material analyzed represents a composite of from two to five samples taken in the same locality. The methods employed for the chemical analysis were those of the official agricultural chemists. The classification of soils adopted in the table of mechanical composition is that of Hall. ${ }^{2}$

1 The subsoil in all cases was taken in connection with the preceding soil sample.

2 The Soil. London, 1908, 2. ed., p. 51. 


\begin{tabular}{|c|c|c|c|c|c|c|c|}
\hline 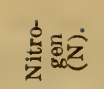 & & 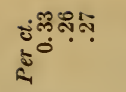 & : & 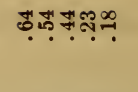 & ชุล & $\stackrel{7}{7}$ & 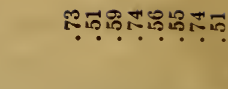 \\
\hline 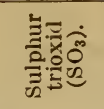 & & 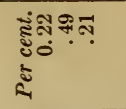 & 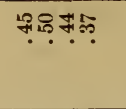 & 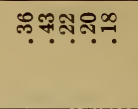 & 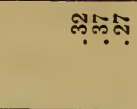 & ஜִ & 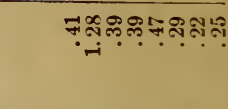 \\
\hline 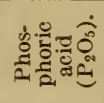 & & 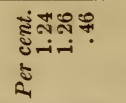 & 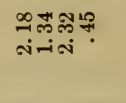 & ฌ: & จุลุิอ & รุ̣ & 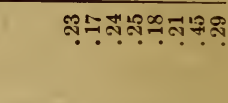 \\
\hline 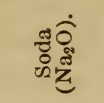 & & 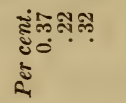 & 워뀨. & 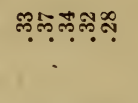 & $\stackrel{\infty}{\because} \div$ & $\dddot{\leftrightarrow}$ & 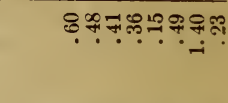 \\
\hline 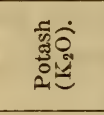 & & 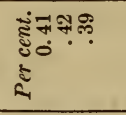 & 촌유눅유 & ุํำำำ? & $\stackrel{-\infty}{\because} \div$ & $\because$ & 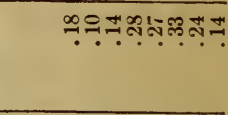 \\
\hline 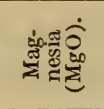 & & 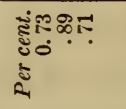 & מִ & 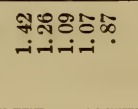 & ชิำ? & $\underset{\infty}{\infty}$ & 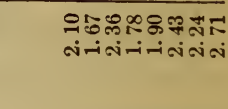 \\
\hline 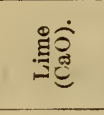 & & 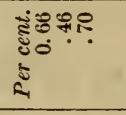 & 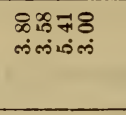 & 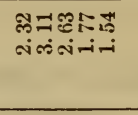 & ตึพิ & ํำ & 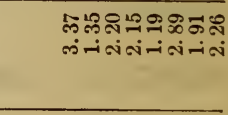 \\
\hline 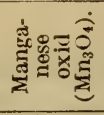 & & 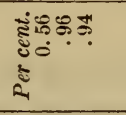 & ธุดำำฺ & 푸ำำำ & 윰쪼 & 8 & 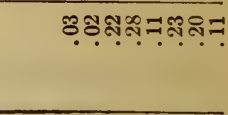 \\
\hline 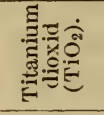 & & 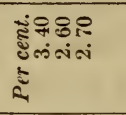 & $\begin{array}{l}08880 \\
\text { - }\end{array}$ & $\begin{array}{cc:}8 \% & \vdots \\
+1 & \vdots \\
\vdots & \vdots\end{array}$ & $\begin{array}{l}\text { 8ิ: } \\
\text { fin } \vdots\end{array}$ & 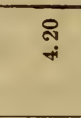 & 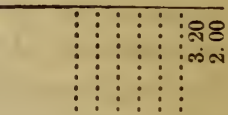 \\
\hline 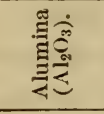 & & 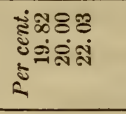 & 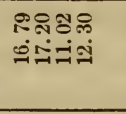 & 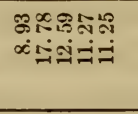 & 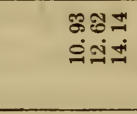 & $\begin{array}{l}\leftrightarrows \\
\stackrel{0}{0}\end{array}$ & 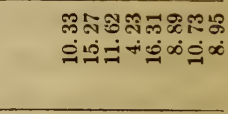 \\
\hline 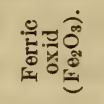 & & 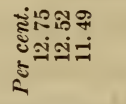 & 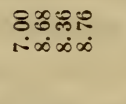 & 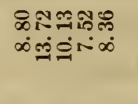 & 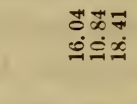 & $\begin{array}{l}\text { สิ } \\
\stackrel{-}{-}\end{array}$ & 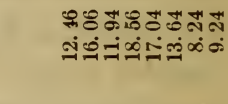 \\
\hline 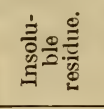 & & 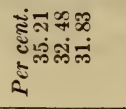 & 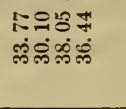 & 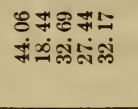 & 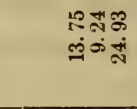 & $\stackrel{9}{9}$ & 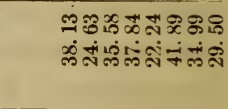 \\
\hline 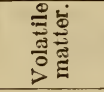 & & 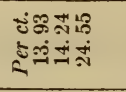 & 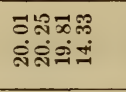 & 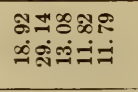 & 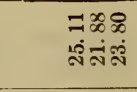 & 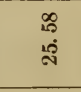 & 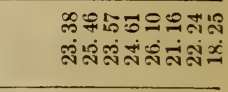 \\
\hline 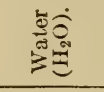 & & 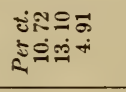 & 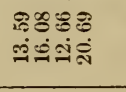 & 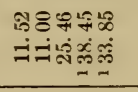 & 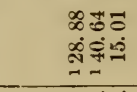 & $\begin{array}{l}8 \\
\dot{9}\end{array}$ & 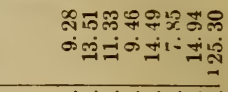 \\
\hline$\dot{0}$ & & 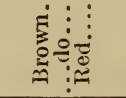 & 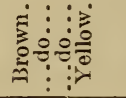 & 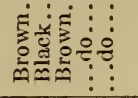 & 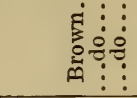 & $\stackrel{\overrightarrow{0}}{0}$ & 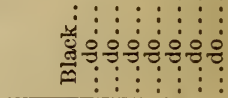 \\
\hline 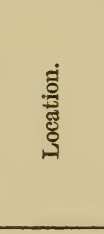 & 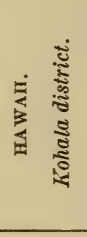 & 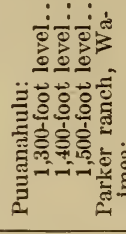 & 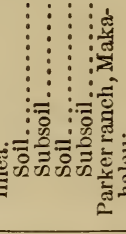 & 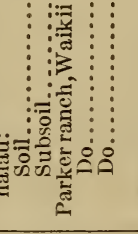 & 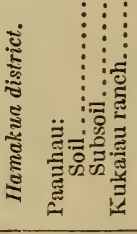 & 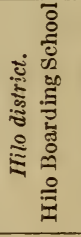 & 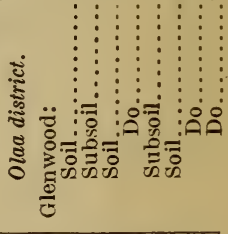 \\
\hline चี & & 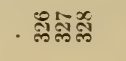 & 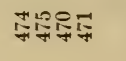 & 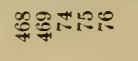 & 森界急 & 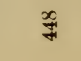 & 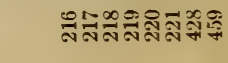 \\
\hline
\end{tabular}


ஜำ นึ้

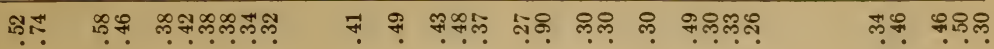

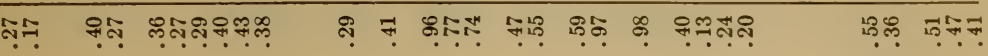

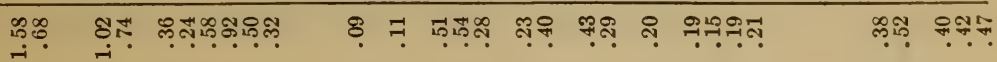

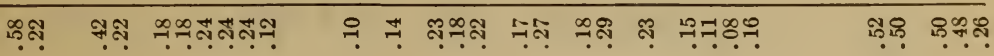

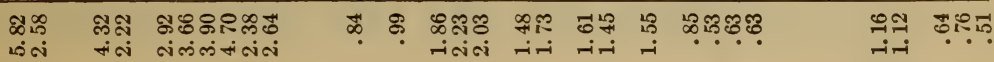

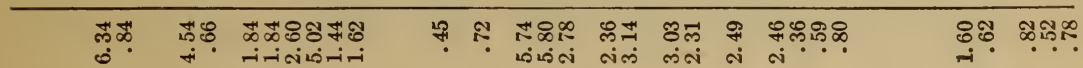

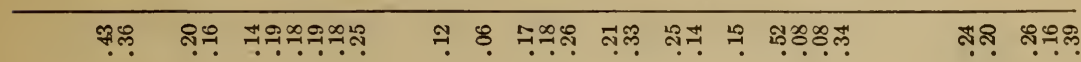

\begin{tabular}{|c|c|c|c|c|c|c|c|c|c|c|}
\hline $\begin{array}{l}\infty 8 \\
\infty 10 \\
\text { ம். }\end{array}$ & $\begin{array}{l}\mathscr{8}: \\
\text { mis } \\
\text { mis }\end{array}$ & & & & 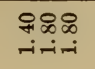 & $\begin{array}{l}8 \% \\
\dot{m}-1\end{array}$ & 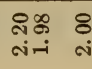 & 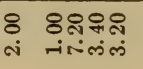 & \$ిষి & $\begin{array}{l}8: 8 \\
\dot{\infty} \sin \end{array}$ \\
\hline ఇ్ֶ & $8 \%$ & 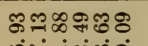 & $\approx$ & $\vec{\sigma}$ & ஜ® & 808 & $\mathrm{~N}:$ & ธิ ㅇำสิก & กิ่ & 재 \\
\hline 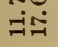 & $\stackrel{\infty}{\infty}$ & ஸ்兀 & $\stackrel{-}{0}$ & $\ddot{\oplus}$ & 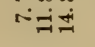 & 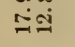 & 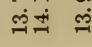 & ๓ & 용 & 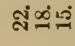 \\
\hline
\end{tabular}

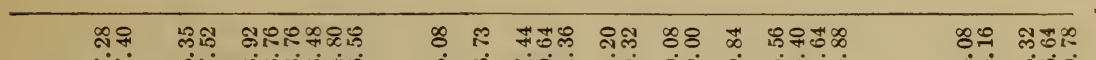

Ni

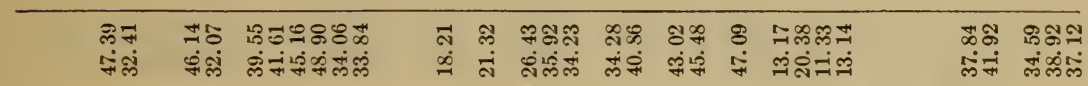

\begin{tabular}{|c|c|c|c|c|c|c|c|c|c|c|c|}
\hline 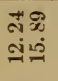 & $\begin{array}{l}\text { i.8 } \\
\text { ing } \\
\text { ing }\end{array}$ & 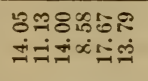 & $\begin{array}{l}\text { की } \\
\text { เุ่ }\end{array}$ & $\underset{\substack{0 \\
\infty}}{\stackrel{0}{0}}$ & 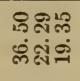 & 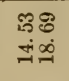 & 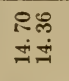 & ঙี & 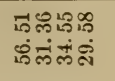 & $\begin{array}{l}\text { 요 } \\
\text { İ }\end{array}$ & 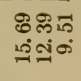 \\
\hline $\begin{array}{l}\text { ஜ: } \\
\text { \&. } \\
+10\end{array}$ & 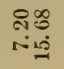 & 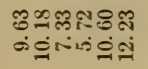 & $\stackrel{\infty}{\infty}$ & 邑 & 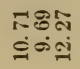 & 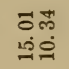 & $\begin{array}{l}10 \% \\
100 \\
0\end{array}$ & $\stackrel{\mathscr{F}}{\infty}$ & 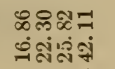 & $\begin{array}{l}5.2 \\
50 \\
150\end{array}$ & 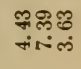 \\
\hline
\end{tabular}

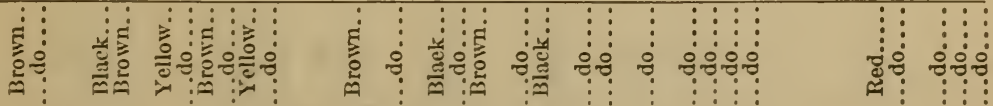

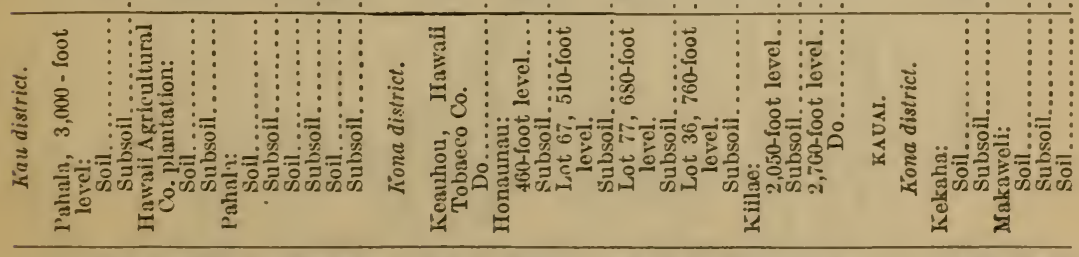

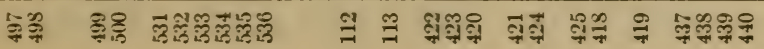




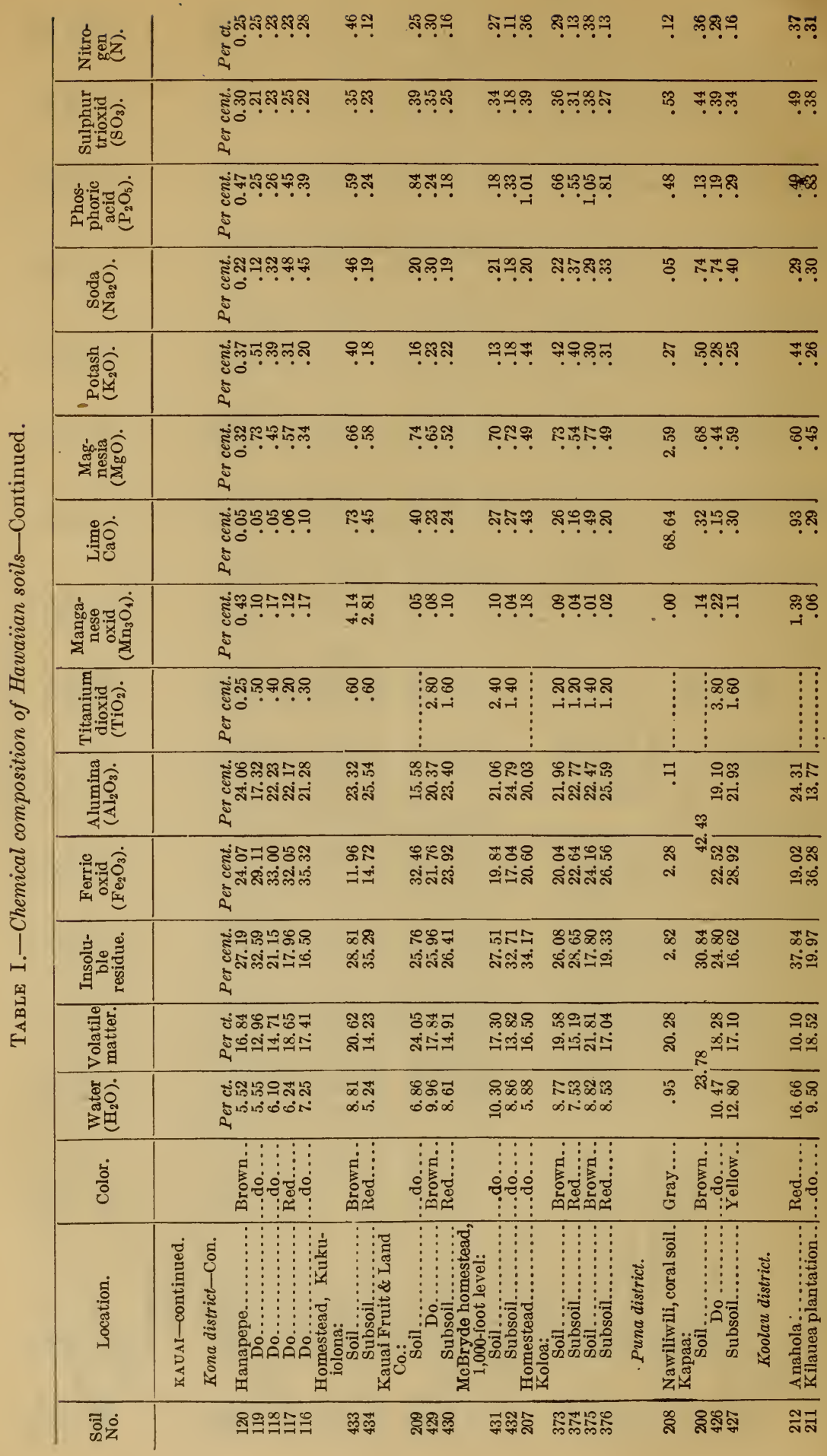




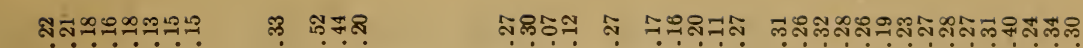

\begin{tabular}{|c|c|c|c|c|}
\hline 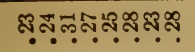 & 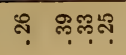 & 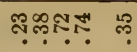 & 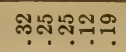 & 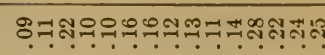 \\
\hline 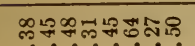 & 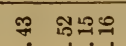 & ิニㄱㄱ ฉ & 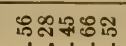 & 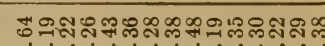 \\
\hline
\end{tabular}

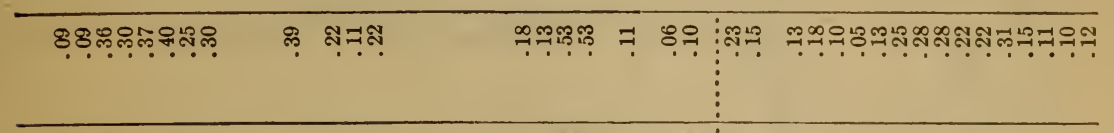

\begin{tabular}{|c|c|c|c|}
\hline 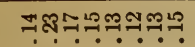 & 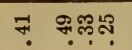 & 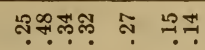 & 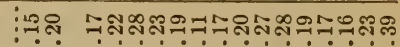 \\
\hline
\end{tabular}

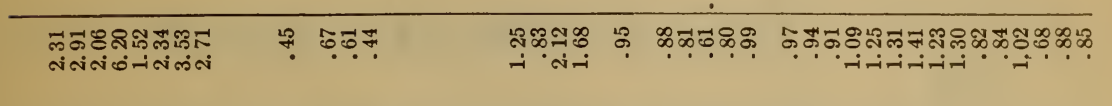

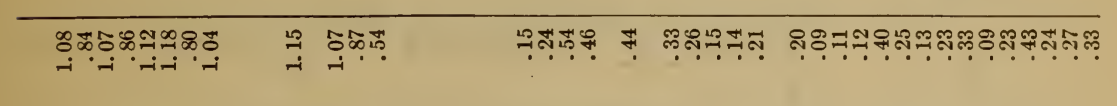

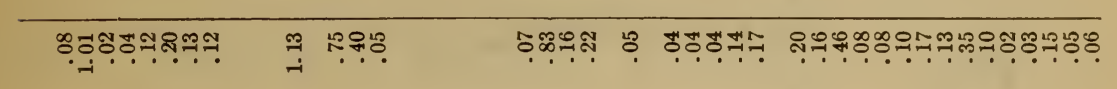

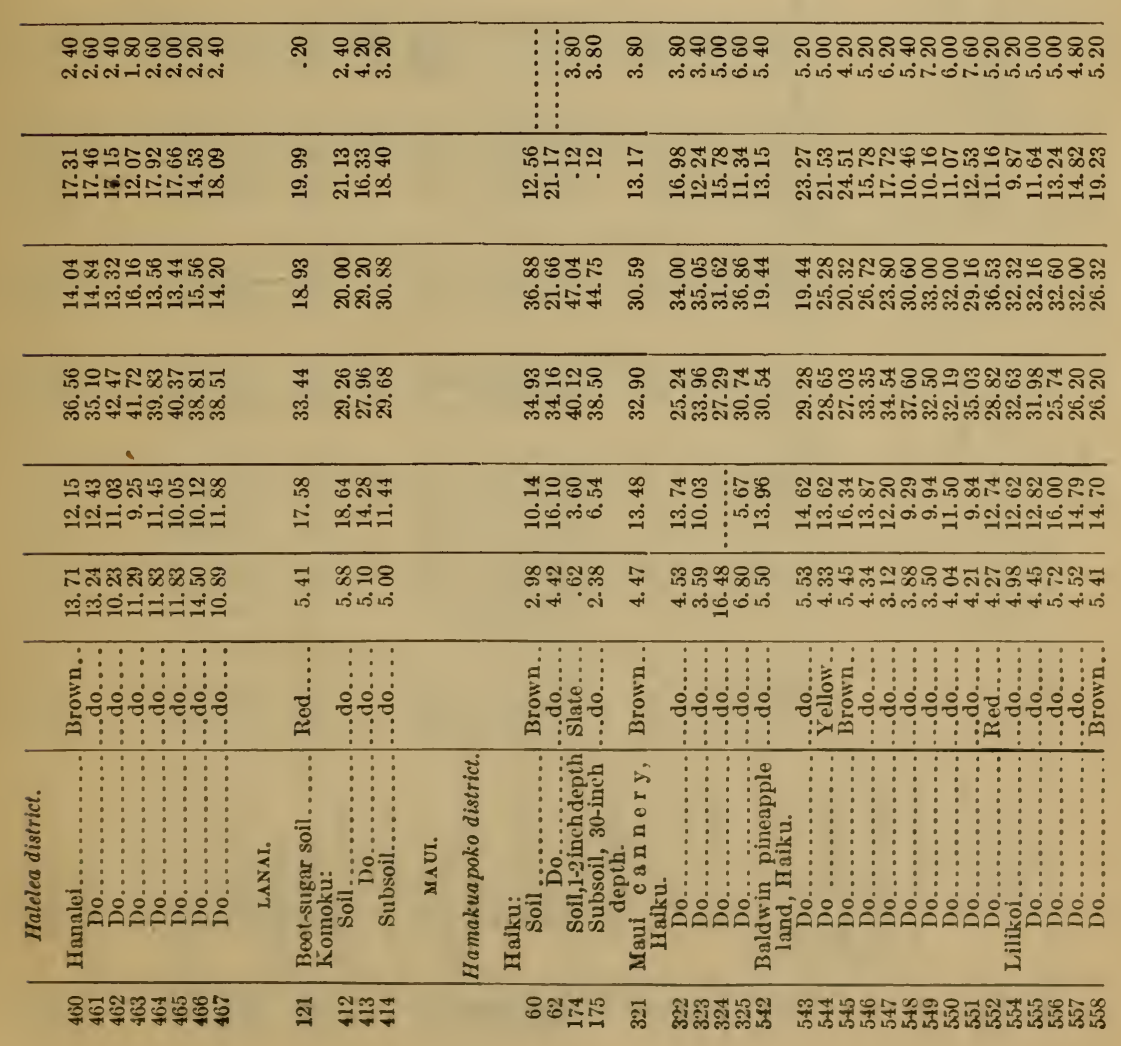




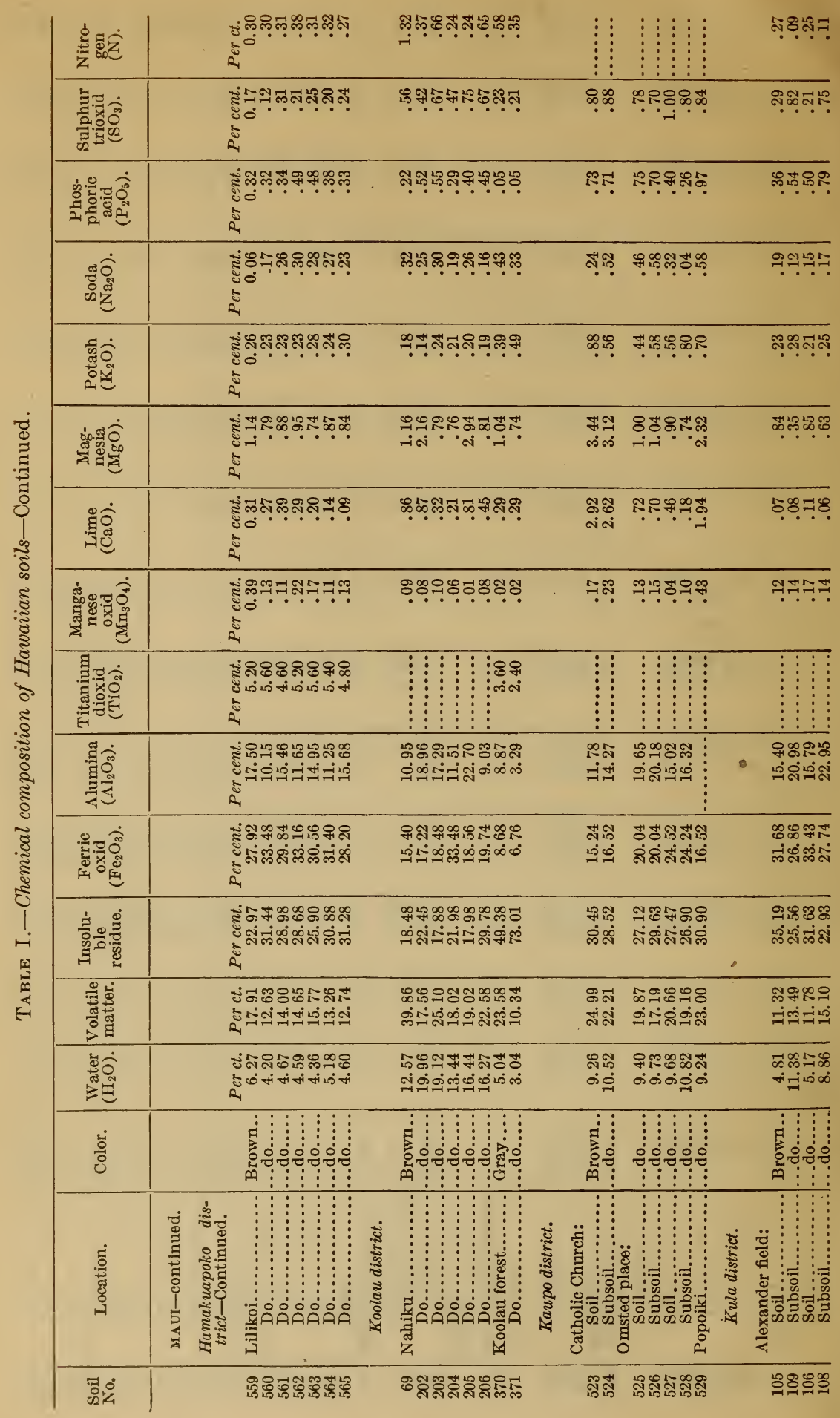




\begin{tabular}{|c|c|c|c|c|c|c|c|c|c|c|}
\hline สุษ & ติ & ชุ่ คุ & 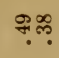 & సి. & ㄴ? & ฐุ. & 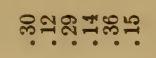 & $\because \mathbb{ー}$ & & 집으 \\
\hline สุร్ & ผุ๋ & ణొఞ & ొ्थे. & 우ำ & దొ్లా & ల్ల. & 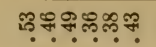 & จุษณำกำ & ๙ุ & $\because ?$ \\
\hline & & & & & & & & & & \\
\hline లో: & ㄷํ. & ฉด. & 옥워 & कo? & $\because R$ & $\stackrel{\infty}{\leftrightarrow}$ & 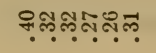 & 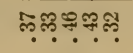 & ? & ڤీ? \\
\hline
\end{tabular}

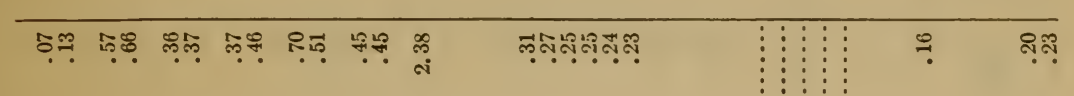

\begin{tabular}{|c|c|c|c|c|c|c|c|c|c|}
\hline$\because$ ㅍ. & 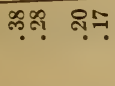 & $\stackrel{9}{?} ?$ & ๙ฺุุ๋ & ๗゙ँ & \% & 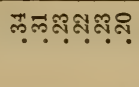 & & ?. & ఇุ. \\
\hline 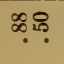 & $\begin{array}{l}8 \infty \\
8 \infty \\
\text { im } \\
\text { im }\end{array}$ & 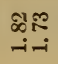 & 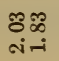 & $\begin{array}{l}\infty \\
\infty \\
-1-1 \\
-1\end{array}$ & is & 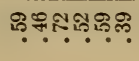 & 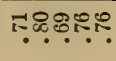 & ำ. & कo \\
\hline
\end{tabular}

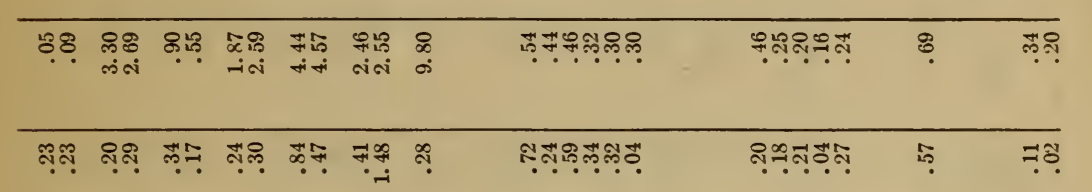

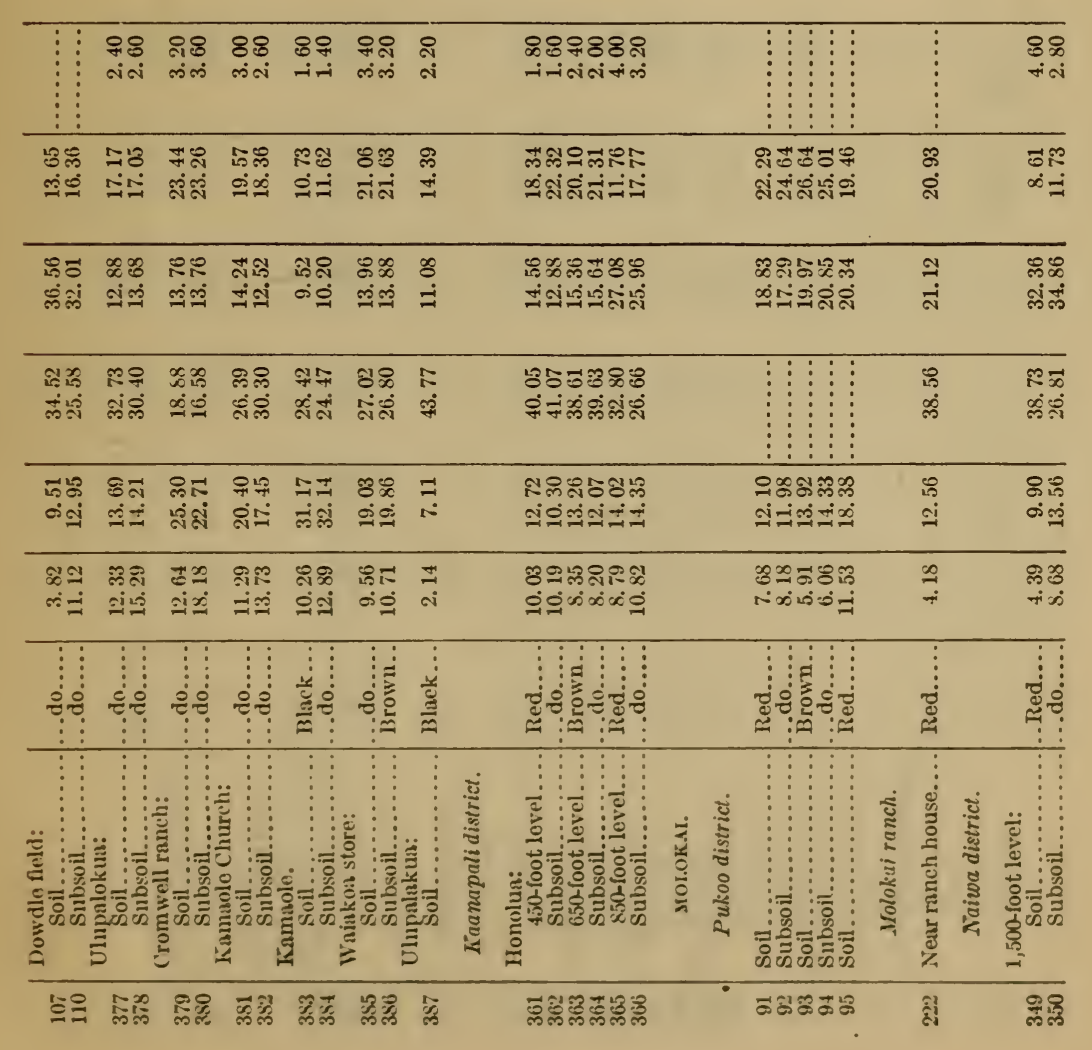




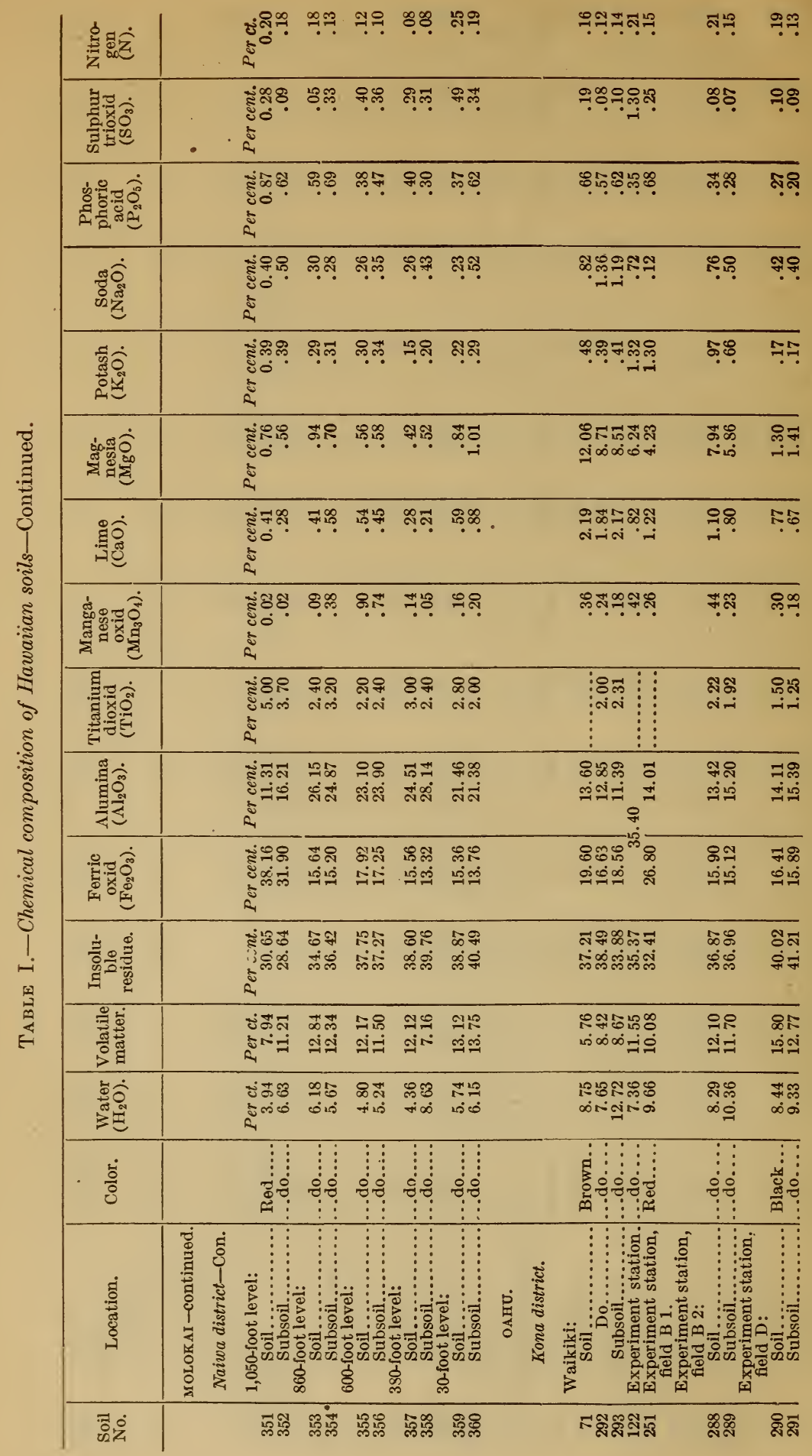




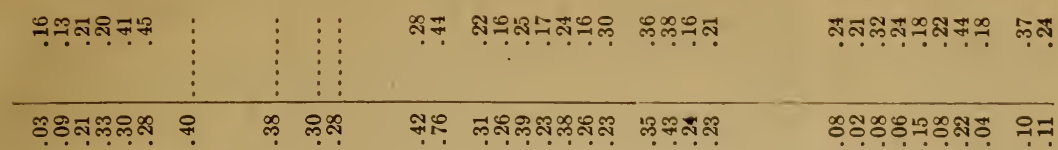

\begin{tabular}{|c|c|c|c|c|c|c|c|c|}
\hline 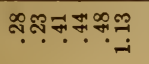 & สุ & & भุल & พุสส & ఈำำำำ & 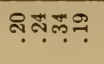 & ำำดำำำ & $\stackrel{\infty}{?: ?}$ \\
\hline 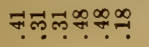 & 유! & $\stackrel{0}{?}$ & 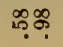 & ঙ্গে & 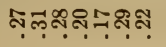 & 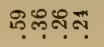 & 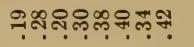 & ำ? \\
\hline
\end{tabular}

\begin{tabular}{|c|c|c|c|c|c|c|}
\hline 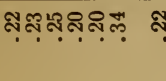 & ๙ొ. & শ্ণে & రి & 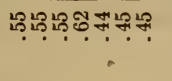 & 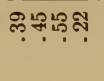 & 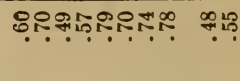 \\
\hline 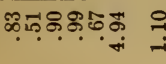 & 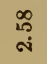 & 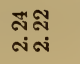 & मค & 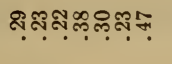 & 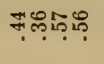 & 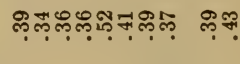 \\
\hline
\end{tabular}

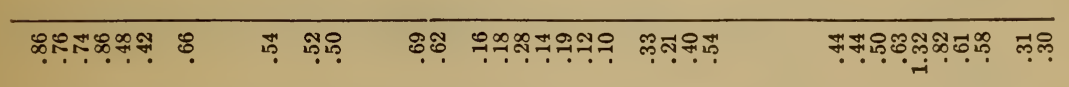

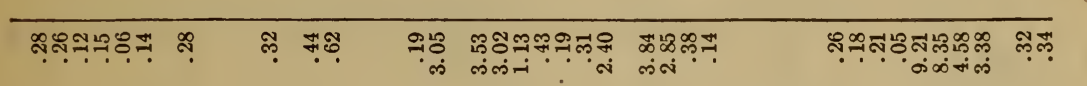

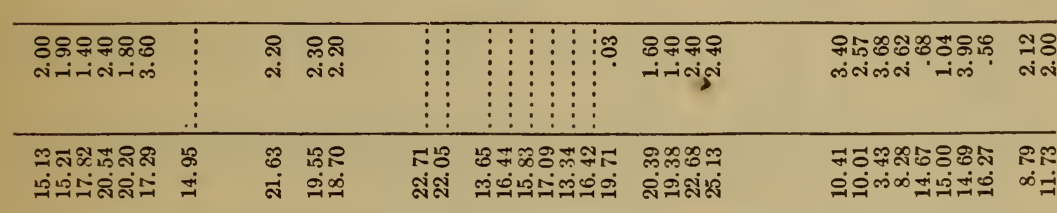

\begin{tabular}{|c|c|c|c|c|c|c|c|c|}
\hline 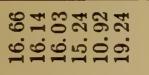 & $\begin{array}{l}\stackrel{0}{-} \\
\text { สं }\end{array}$ & $\begin{array}{l}\overleftrightarrow{O} \\
\text { İ }\end{array}$ & $\begin{array}{l}\text { Noर } \\
\text { ș }\end{array}$ & 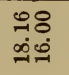 & 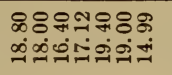 & 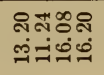 & 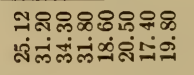 & 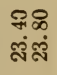 \\
\hline 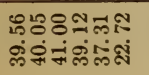 & $\begin{array}{l}\stackrel{N}{N} \\
\text { 今ं }\end{array}$ & $\underset{\substack{\infty \\
\infty}}{\mathbb{\infty}}$ & 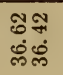 & $\begin{array}{l}\text { FR } \\
\text { मृं }\end{array}$ & 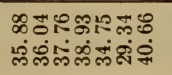 & 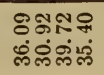 & 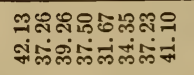 & $\begin{array}{l}\qquad 8 \pi \\
\dot{y}+20\end{array}$ \\
\hline 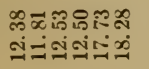 & $\stackrel{\infty}{\stackrel{\infty}{\sim}}$ & 苞 & 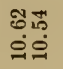 & 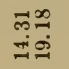 & 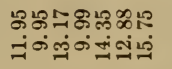 & 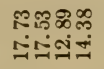 & 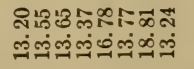 & 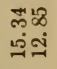 \\
\hline 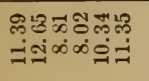 & R & 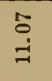 & 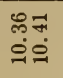 & 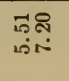 & 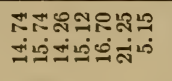 & 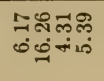 & 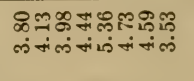 & 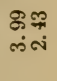 \\
\hline
\end{tabular}

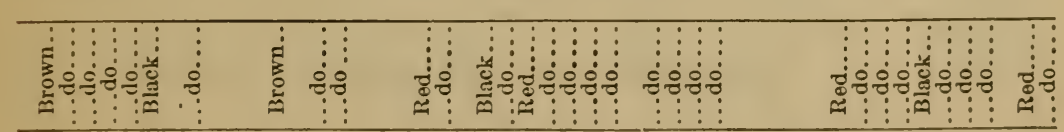

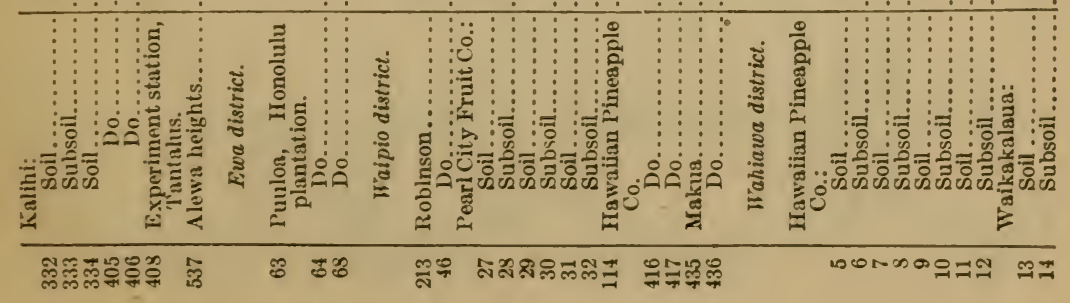




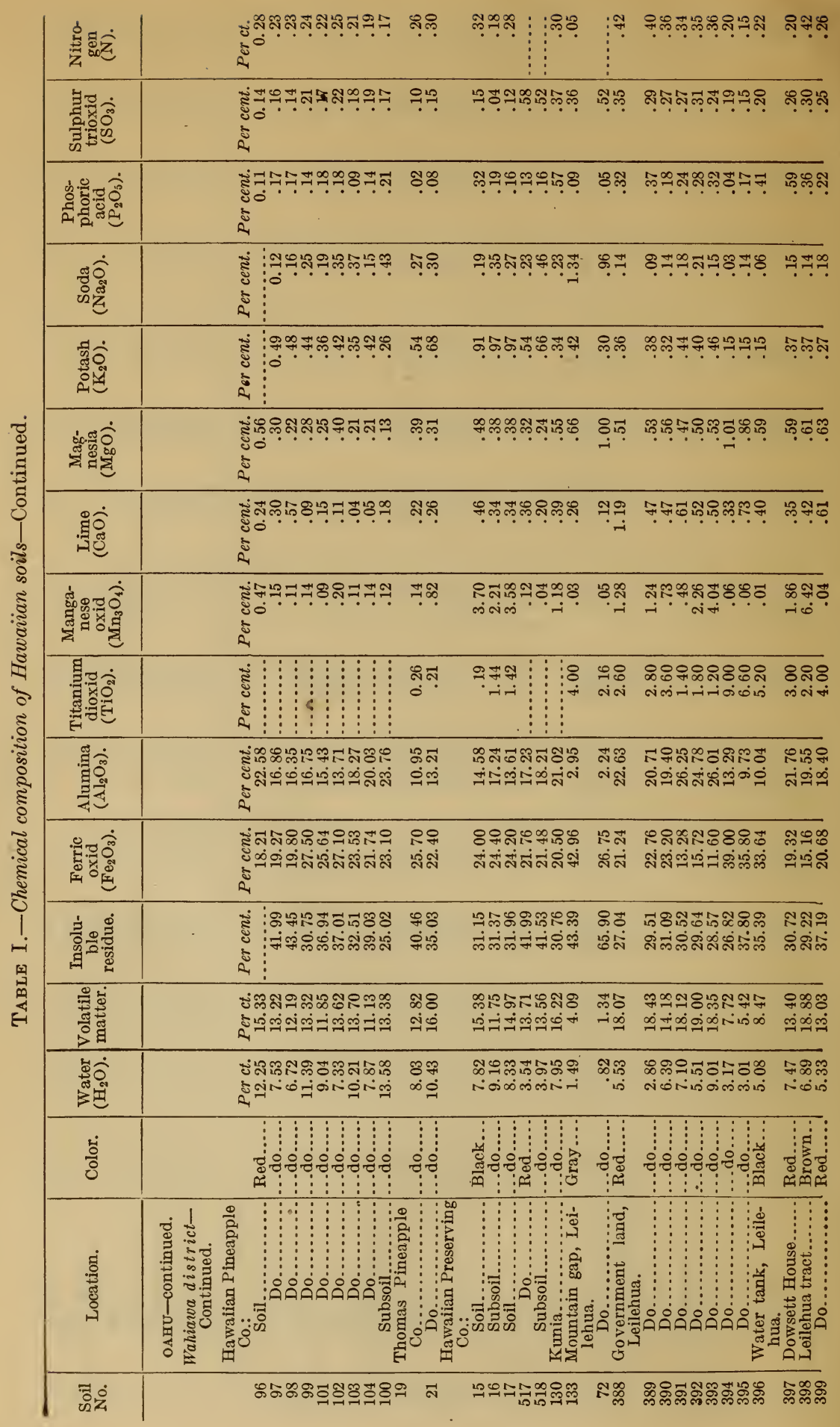




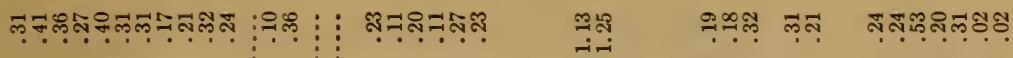

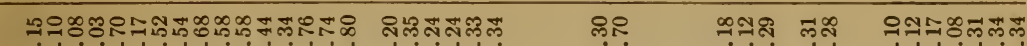

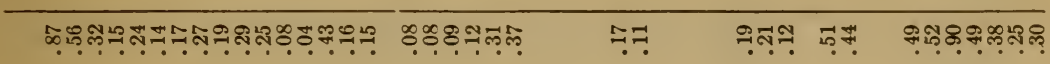

\begin{tabular}{|c|c|c|c|c|c|}
\hline 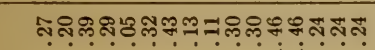 & 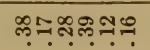 & శ্ণฺ & สฺฺุุุ & ำ? & ్రి \\
\hline
\end{tabular}

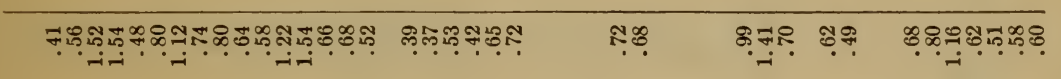

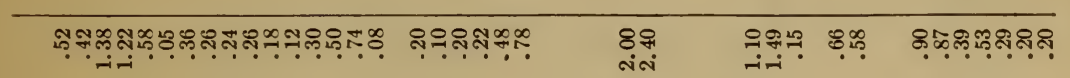

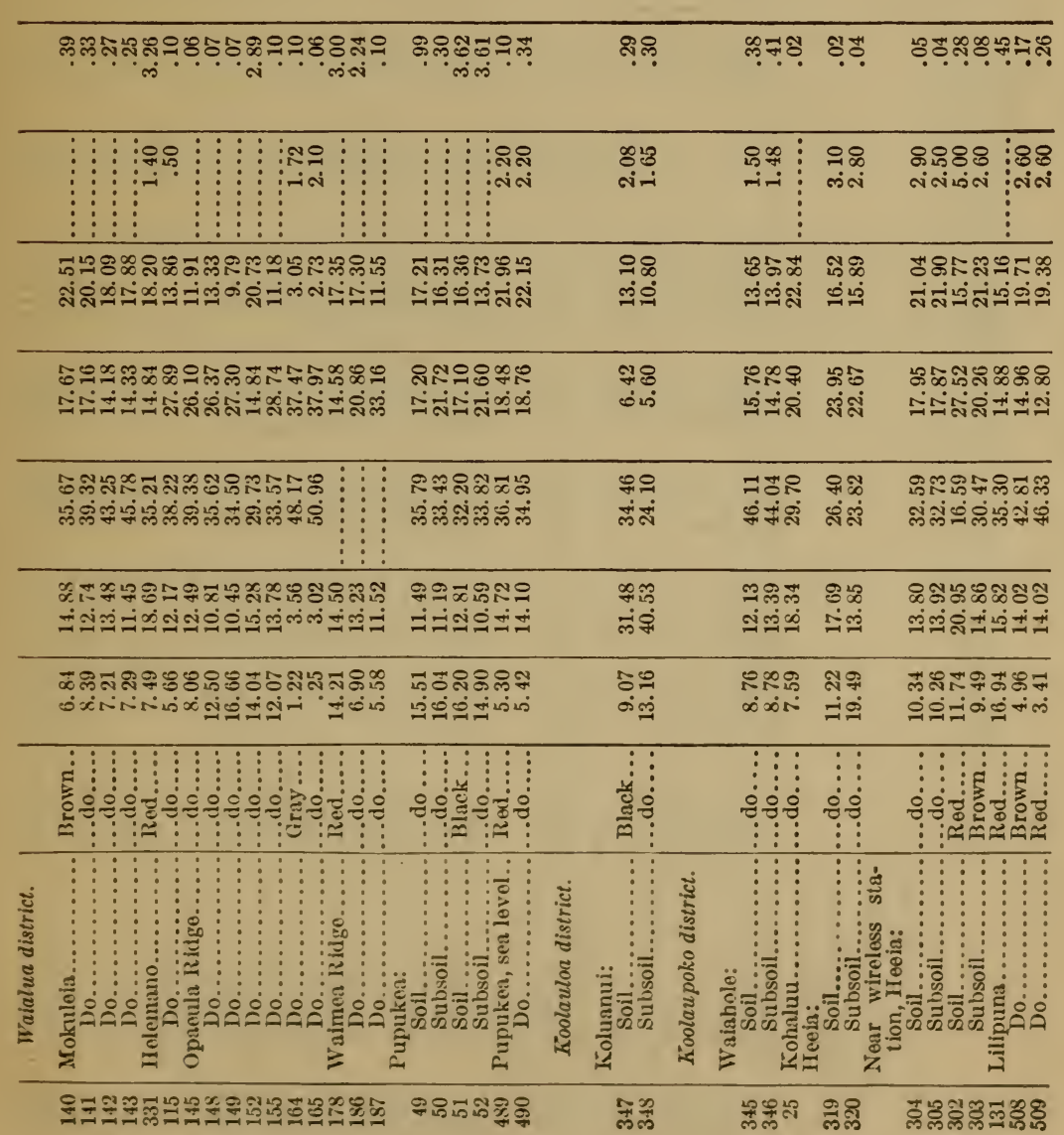




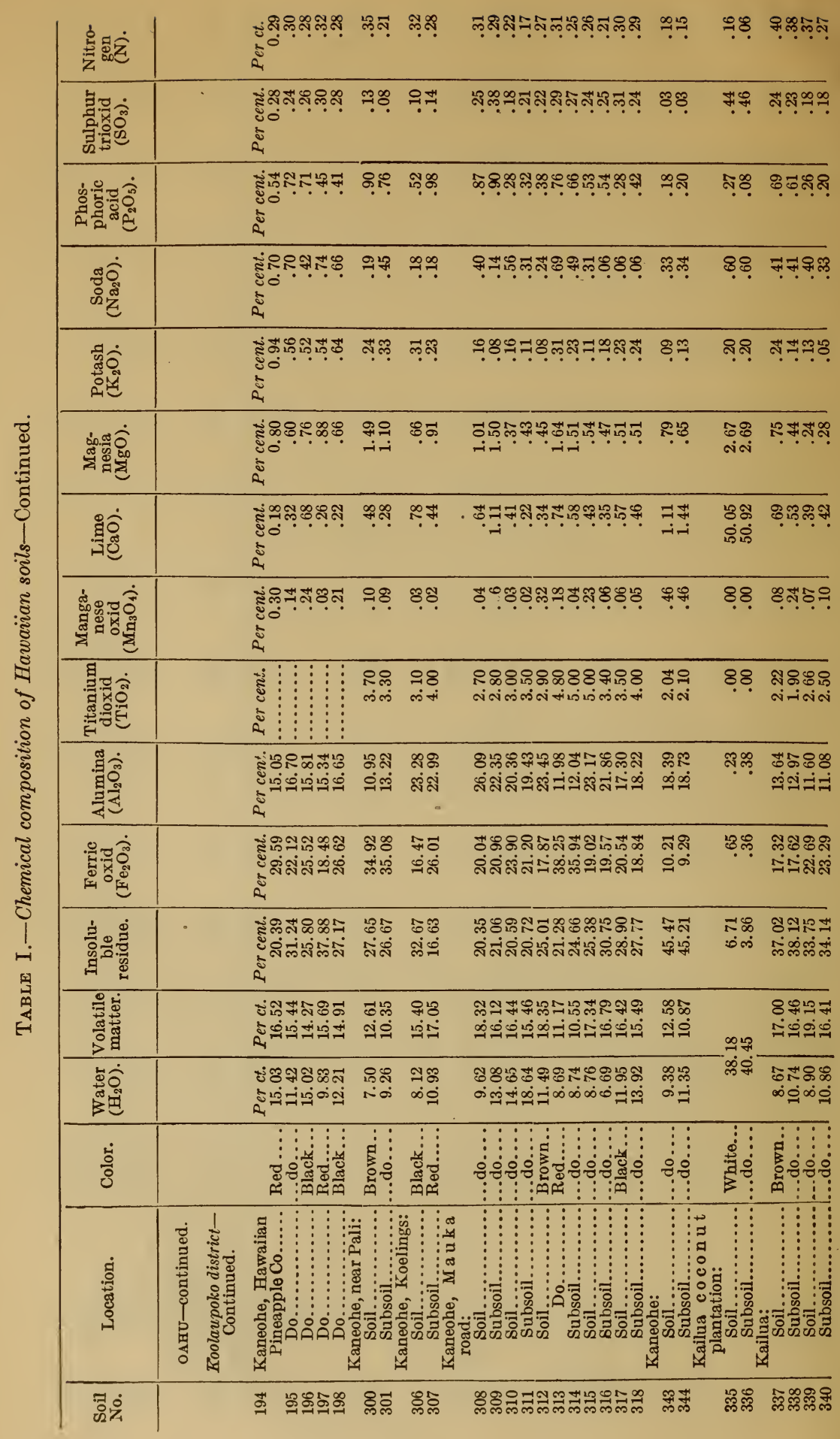




\begin{tabular}{|c|c|c|c|}
\hline 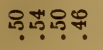 & 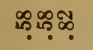 & 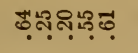 & รุి \\
\hline 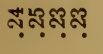 & 적우ำ & 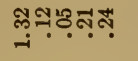 & ஓ्ष \\
\hline 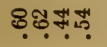 & 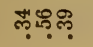 & 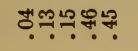 & कุष. \\
\hline 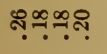 & 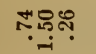 & 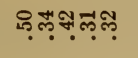 & సฺ̣ \\
\hline 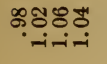 & 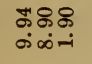 & 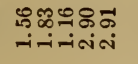 & ?: \\
\hline 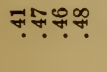 & 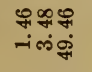 & 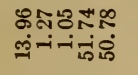 & భִ: \\
\hline 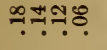 & ఘฺฺุุ. & 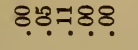 & 苞 \\
\hline 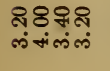 & $\begin{array}{l}\text { 요 } \\
\text { iim }\end{array}$ & & $\begin{array}{l}\text { สః } \\
\text { สं }\end{array}$ \\
\hline 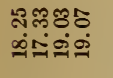 & $\begin{array}{l}\text { RR: } \\
\text { Rog } \\
\text { ogd }\end{array}$ & 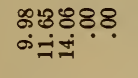 & 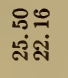 \\
\hline 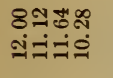 & 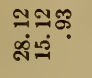 & 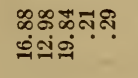 & 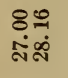 \\
\hline 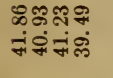 & 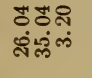 & 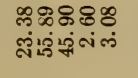 & 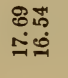 \\
\hline 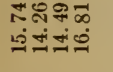 & 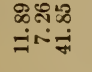 & 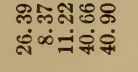 & 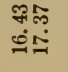 \\
\hline 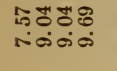 & 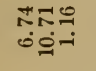 & 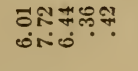 & 跑: \\
\hline & & 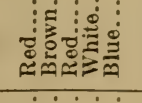 & 言: \\
\hline & . & 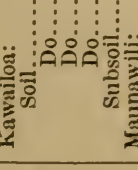 & 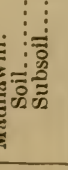 \\
\hline 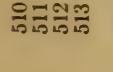 & & 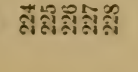 & \\
\hline
\end{tabular}


TABLE II.-Humus, humus ash, and total nitrogen in Hawaiian soils.

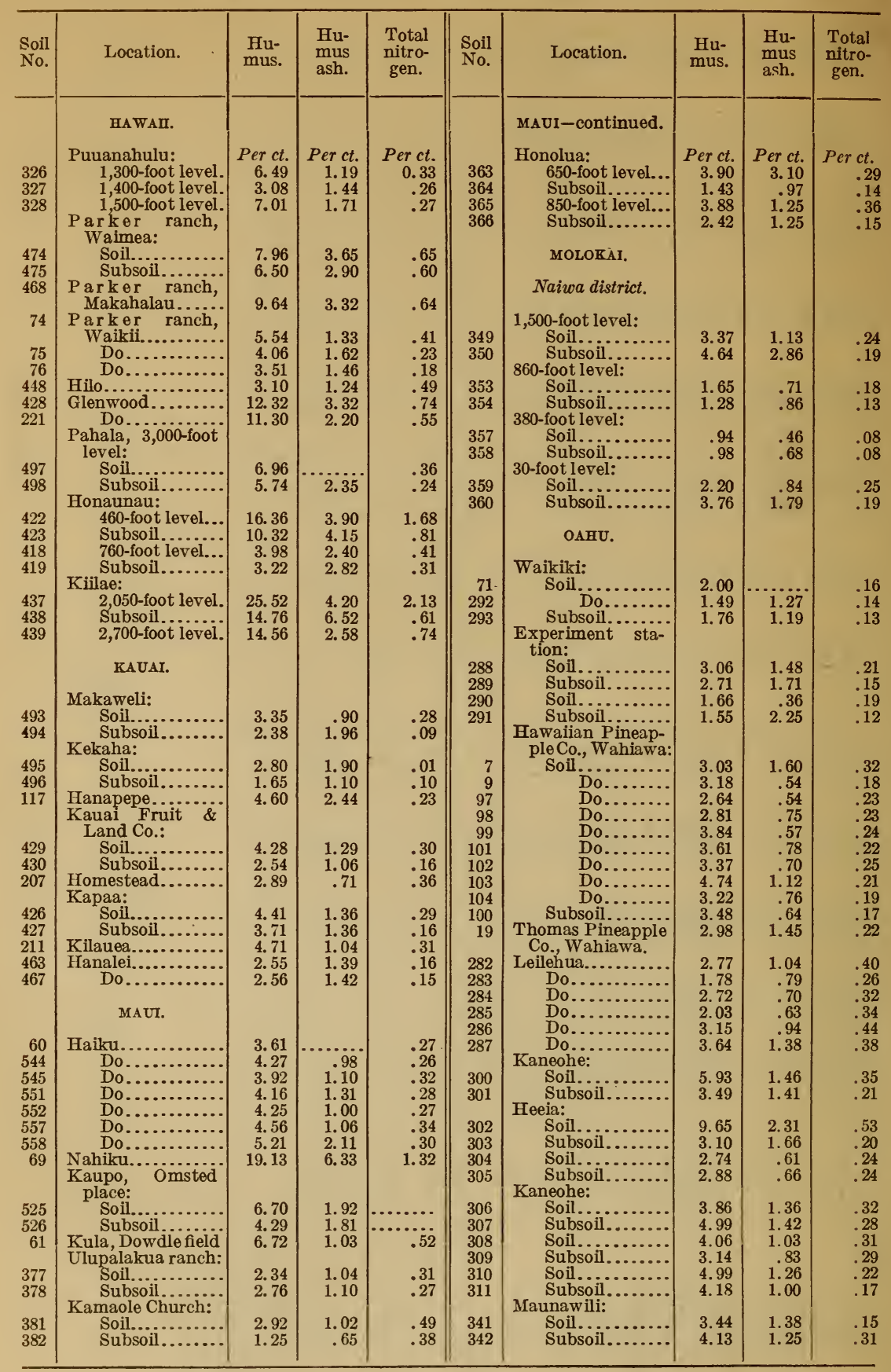


TABLE III.-Mechanical composition of Hawaiian soils.

\begin{tabular}{|c|c|c|c|c|c|c|c|c|}
\hline $\begin{array}{l}\text { Soil } \\
\text { No. }\end{array}$ & Location. & $\begin{array}{l}\text { Volatile } \\
\text { matter. }\end{array}$ & $\begin{array}{l}\text { Fine } \\
\text { gravel. }\end{array}$ & $\begin{array}{l}\text { Coarse } \\
\text { sand. }\end{array}$ & $\begin{array}{l}\text { Fine } \\
\text { sand. }\end{array}$ & Silt. & Fine silt. & Clay. \\
\hline & HAWAII. & & & & & & & \\
\hline & Kohala district. & & & & & & & \\
\hline $\begin{array}{r}326 \\
327 \\
328 \\
74 \\
75 \\
76 \\
573\end{array}$ & $\begin{array}{r}\text { Puusnahulu: } \\
1,300-\text { foot level........ } \\
1,400-\text { foot level....... } \\
1,500 \text {-foot level...... } \\
\text { Parker ranch, Waikii.... } \\
\text { Do...................... } \\
\text { Do.................... } \\
\text { Do................ }\end{array}$ & $\begin{array}{r}\text { Per cent. } \\
17.15 \\
18.31 \\
17.41 \\
25.83 \\
21.75 \\
19.45 \\
23.30\end{array}$ & $\begin{array}{r}\text { Per cent. } \\
0.22 \\
.24 \\
.34 \\
1 . \\
.03 \\
.02 \\
1.7\end{array}$ & $\begin{array}{r}\text { Per cent. } \\
0.58 \\
\\
\quad .65 \\
64 \\
64 \\
\\
\\
\\
71 \\
71.48 \\
2.14\end{array}$ & $\begin{array}{r}\text { Per cent. } \\
22.48 \\
30.46 \\
22.86 \\
38.03 \\
29.50 \\
26.70 \\
36.20\end{array}$ & $\begin{array}{r}\text { Per cent. } \\
19.28 \\
17.58 \\
14.81 \\
16.22 \\
18.65 \\
22.90 \\
21.82\end{array}$ & $\begin{array}{r}\text { Per cent. } \\
28.64 \\
20.73 \\
25.15 \\
19.99 \\
20.75 \\
24.45 \\
13.60\end{array}$ & $\begin{array}{r}\text { Fer cent. } \\
13.54 \\
13.26 \\
19.94 \\
2.05 \\
4.48 \\
3.55 \\
3.75\end{array}$ \\
\hline & Hilo district. & & & & & & & \\
\hline 448 & $\begin{array}{c}\text { Hilo...................... } \\
\text { Olaa district. }\end{array}$ & 32.95 & 1.94 & 8.60 & 16.31 & 13.45 & 20.00 & 6.85 \\
\hline 428 & $\begin{array}{c}\text { Glenwood............... } \\
\text { Kona district. }\end{array}$ & 29.85 & 13.81 & 32.82 & 15.83 & 5.38 & 1.76 & .69 \\
\hline $\begin{array}{l}111 \\
112 \\
113\end{array}$ & $\begin{array}{l}\text { Keahui............. } \\
\text { Do............... } \\
\text { Do............ } \\
\text { Hanauhau: }\end{array}$ & $\begin{array}{l}22.65 \\
32.70 \\
33.60\end{array}$ & $\begin{array}{l}.00 \\
.07 \\
.12\end{array}$ & $\begin{array}{r}14.42 \\
3.22 \\
2.49\end{array}$ & $\begin{array}{l}32.15 \\
17.60 \\
15.23\end{array}$ & $\begin{array}{l}12.65 \\
15.70 \\
13.62\end{array}$ & $\begin{array}{l}14.17 \\
24.50 \\
25.80\end{array}$ & $\begin{array}{l}5.38 \\
6.58 \\
7.10\end{array}$ \\
\hline $\begin{array}{l}422 \\
423 \\
420 \\
421 \\
424 \\
425 \\
418 \\
419\end{array}$ & 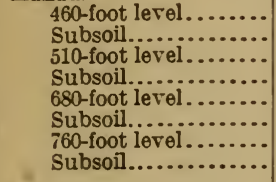 & $\begin{array}{l}43.50 \\
26.97 \\
22.93 \\
19.12 \\
20.30 \\
16.87 \\
17.95 \\
13.42\end{array}$ & $\begin{array}{l}1.66 \\
1.97 \\
2.17 \\
.49 \\
3.18 \\
3.95 \\
3.10 \\
5.25\end{array}$ & $\begin{array}{l}1.87 \\
2.98 \\
2.26 \\
1.29 \\
3.99 \\
5.15 \\
3.04 \\
5.10\end{array}$ & $\begin{array}{l}26.29 \\
36.75 \\
16.62 \\
16.31 \\
22.15 \\
22.02 \\
20.72 \\
19.43\end{array}$ & $\begin{array}{l}16.03 \\
21.63 \\
17.46 \\
14.07 \\
21.63 \\
19.58 \\
21.04 \\
19.19\end{array}$ & $\begin{array}{r}10.33 \\
9.19 \\
31.88 \\
35.48 \\
23.61 \\
25.76 . \\
27.65 \\
28.52\end{array}$ & $\begin{array}{r}1.07 \\
.99 \\
7.16 \\
14.03 \\
3.98 \\
6.29 \\
6.67 \\
9.09\end{array}$ \\
\hline & $\begin{array}{c}\text { EAUAI. } \\
\text { Eona district. }\end{array}$ & & & & & & & \\
\hline $\begin{array}{l}116 \\
117 \\
118 \\
119 \\
120\end{array}$ & 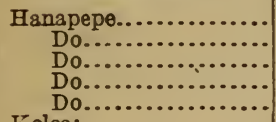 & $\begin{array}{l}18.75 \\
19.90 \\
15.60 \\
13.74 \\
17.85\end{array}$ & $\begin{array}{r}.02 \\
.10 \\
1.2 \\
.3 \\
1.4\end{array}$ & $\begin{array}{l}1.57 \\
3.11\end{array}$ & $\begin{array}{r}5.48 \\
7.58 \\
11.78 \\
5.72 \\
4.17\end{array}$ & $\begin{array}{r}6.49 \\
7.22 \\
11.65 \\
4.65 \\
4.43\end{array}$ & $\begin{array}{l}33.40 \\
36.50 \\
24.20 \\
33.20 \\
34.20\end{array}$ & $\begin{array}{l}.5 .50 \\
27.40 \\
35.80 \\
43.70 \\
39.10\end{array}$ \\
\hline $\begin{array}{l}373 \\
374 \\
375 \\
376\end{array}$ & $\begin{array}{l}\text { Koloa: } \\
\text { Soil................... } \\
\text { Subsoil............... } \\
\text { Soil................. } \\
\text { Subsoil.............. }\end{array}$ & $\begin{array}{l}21.41 \\
16.42 \\
25.28 \\
19.21\end{array}$ & $\begin{array}{l}.10 \\
.06 \\
.24 \\
.12\end{array}$ & $\begin{array}{l}.40 \\
.12 \\
.42 \\
.45\end{array}$ & $\begin{array}{r}9.66 \\
11.88 \\
18.35 \\
26.89\end{array}$ & $\begin{array}{r}12.78 \\
9.04 \\
10.31 \\
13.37\end{array}$ & $\begin{array}{l}29.01 \\
22.28 \\
32.45 \\
20.69\end{array}$ & $\begin{array}{l}27.24 \\
41.09 \\
15.04 \\
20.92\end{array}$ \\
\hline & $\begin{array}{c}\text { MAUT. } \\
\text { Hamakuapoko district. }\end{array}$ & & & & & & & \\
\hline 61 & $\begin{array}{c}\text { Haiku } \\
\text { Koolau district. }\end{array}$ & 25.16 & .12 & 7.20 & 40.90 & 9.85 & 15.01 & 2.93 \\
\hline 69 & $\begin{array}{c}\text { Nahiku.................. } \\
\text { Kula district. }\end{array}$ & 44.60 & 5.94 & 26.72 & 8.65 & 4.07 & 5.09 & 5.78 \\
\hline $\begin{array}{l}105 \\
109 \\
106 \\
108\end{array}$ & $\begin{array}{l}\text { Alexander field: } \\
\text { Soil.................... } \\
\text { Subsoil................ } \\
\text { Soil................. } \\
\text { Subsoil ............. } \\
\text { Dowdle field: }\end{array}$ & $\begin{array}{l}11.59 \\
14.80 \\
12.00 \\
15.55\end{array}$ & $\begin{array}{l}0.9 \\
0.5 \\
1.1 \\
0.9\end{array}$ & & $\begin{array}{r}20.40 \\
5.71 \\
20.40 \\
13.58\end{array}$ & $\begin{array}{l}9.53 \\
5.62 \\
9.26 \\
6.25\end{array}$ & $\begin{array}{l}35.80 \\
11.55 \\
36.30 \\
13.35\end{array}$ & $\begin{array}{l}22.55 \\
64.10 \\
21.85 \\
51.26\end{array}$ \\
\hline $\begin{array}{l}107 \\
110\end{array}$ & & $\begin{array}{l}10.57 \\
14.92\end{array}$ & $\begin{array}{l}1.2 \\
0.9\end{array}$ & & $\begin{array}{r}21.21 \\
5.18\end{array}$ & $\begin{array}{r}10.63 \\
7.77\end{array}$ & $\begin{array}{l}39.88 \\
17.20\end{array}$ & $\begin{array}{l}15.87 \\
54.30\end{array}$ \\
\hline $\begin{array}{l}361 \\
362 \\
363 \\
364 \\
365 \\
366\end{array}$ & $\begin{array}{l}\text { Kaanapali district. } \\
\text { Honolua: } \\
\text { 450-foot level....... } \\
\text { Subsoll........... } \\
650 \text {-foot level...... } \\
\text { Subsoil........... } \\
850 \text {-foot level...... } \\
\text { Subsoll............ }\end{array}$ & $\begin{array}{l}16.22 \\
13.09 \\
16.11 \\
13.32 \\
16.46 \\
17.22\end{array}$ & $\begin{array}{l}.64 \\
.08 \\
.43 \\
.05 \\
.01 \\
.07\end{array}$ & $\begin{array}{r}.94 \\
.12 \\
.68 \\
.24 \\
1.90 \\
.15\end{array}$ & $\begin{array}{r}39.51 \\
14.47 \\
19.79 \\
13.09 \\
11.64 \\
4.02\end{array}$ & $\begin{array}{r}16.02 \\
10.84 \\
17.59 \\
11.63 \\
20.89 \\
7.11\end{array}$ & $\begin{array}{r}9.73 \\
26.43 \\
26.51 \\
29.11 \\
37.95 \\
18.64\end{array}$ & $\begin{array}{l}17.36 \\
35.57 \\
19.39 \\
33.32 \\
13.89 \\
54.11\end{array}$ \\
\hline
\end{tabular}


TABLE III.-Mechanical composition of Hawaiian soils-Continued.

\begin{tabular}{|c|c|c|c|c|c|c|c|c|}
\hline $\begin{array}{l}\text { Soil } \\
\text { No. }\end{array}$ & Location. & $\begin{array}{l}\text { Volatile } \\
\text { matter. }\end{array}$ & $\begin{array}{l}\text { Fine } \\
\text { gravel. }\end{array}$ & $\begin{array}{l}\text { Coarse } \\
\text { sand. }\end{array}$ & $\begin{array}{l}\text { Fine } \\
\text { sand. }\end{array}$ & Silt. & Fine silt. & Clay. \\
\hline & MOLOKAI. & & & & & & & \\
\hline & Naiwa distr & & & & & & & \\
\hline 349 & $\begin{array}{l}\text { 1,500-foot level: } \\
\text { Soil............ }\end{array}$ & $\begin{array}{r}\text { Percent. } \\
10.71\end{array}$ & $\begin{array}{r}\text { Per cent. } \\
0.46\end{array}$ & $\begin{array}{r}\text { Per cent. } \\
1.00\end{array}$ & $\begin{array}{r}\text { Per cent. } \\
22.05\end{array}$ & $\begin{array}{r}\text { Per cent. } \\
12.34\end{array}$ & $\begin{array}{r}\text { Per cent. } \\
45.95\end{array}$ & $\begin{array}{r}\text { Per cent. } \\
8.91\end{array}$ \\
\hline 350 & $\begin{array}{l}\text { Subsoil........................ } \\
\text { 1,050-foot level: }\end{array}$ & 16.38 & .03 & .24 & 9.80 & 8.99 & 27.20 & 39.70 \\
\hline \multirow{2}{*}{$\begin{array}{l}351 \\
352\end{array}$} & Soil...................... & 9.06 & .08 & .36 & 13.89 & 20.32 & 45.99 & 10.98 \\
\hline & $\begin{array}{l}\text { Subsoil...... } \\
\text { 860-foot level: }\end{array}$ & 18.18 & .01 & .16 & $11.41^{\circ}$ & 9.09 & 24.99 & 43.2 \\
\hline \multirow{2}{*}{$\begin{array}{l}353 \\
354\end{array}$} & Soil.......... & 15.24 & .03 & .41 & 35.86 & 18.59 & 18.78 & 12.09 \\
\hline & $\begin{array}{l}\text { Subsoil..... } \\
\text { 600-foot level: }\end{array}$ & 13.54 & .05 & .54 & 30.67 & 20.49 & 19.05 & 16.10 \\
\hline \multirow{2}{*}{$\begin{array}{l}355 \\
356\end{array}$} & Soil........ & 13.05 & .01 & .73 & 36.15 & 14.89 & 19.47 & 15.85 \\
\hline & $\begin{array}{l}\text { Subsoil...: } \\
\text { 380-foot level: }\end{array}$ & 12.48 & .00 & .86 & 40.41 & 15.35 & 18.06 & 14.2 \\
\hline \multirow{2}{*}{$\begin{array}{l}357 \\
358\end{array}$} & Soil.......... & 12.95 & .03 & .23 & 39.84 & 17.72 & 14.40 & 14.97 \\
\hline & $\begin{array}{l}\text { Subsoil.... } \\
\text { 30-foot level: }\end{array}$ & 12.98 & .00 & .15 & 40.54 & 14.96 & 13.67 & 17.75 \\
\hline \multirow[t]{3}{*}{$\begin{array}{l}\mathbf{3 5 9} \\
360\end{array}$} & $\begin{array}{l}\text { Soil......... } \\
\text { Subsoil..... }\end{array}$ & $\begin{array}{l}15.39 \\
17.82\end{array}$ & $\begin{array}{l}.25 \\
.00\end{array}$ & $\begin{array}{l}.55 \\
.13\end{array}$ & $\begin{array}{l}44.65 \\
48.13\end{array}$ & $\begin{array}{l}21.98 \\
23.73\end{array}$ & $\begin{array}{l}9.91 \\
6.59\end{array}$ & $\begin{array}{l}7.45 \\
3.96\end{array}$ \\
\hline & OAHU. & & & & & & & \\
\hline & Kona district. & & & & & & & \\
\hline 292 & Waikiki: & 8.71 & 20.91 & 18.75 & 22,04 & 8.69 & 12,41 & \\
\hline \multirow[t]{2}{*}{293} & Subsoil. & 10.77 & 18.61 & 18.30 & 22.74 & 8.10 & $\begin{array}{l}12.41 \\
13.48\end{array}$ & 9.52 \\
\hline & $\begin{array}{l}\text { Experiment } \\
\text { Soil..... }\end{array}$ & 14.42 & .85 & 7.92 & 16.19 & 10.8 & 25.31 & 24.89 \\
\hline 289 & Subsoil.. & 13.82 & .56 & 6.16 & 8.89 & 6. & 24.07 & 40.35 \\
\hline 290 & Soil........ & 16.22 & .14 & .58 & 7.7 & 9. & 18.14 & 48.35 \\
\hline 291 & Subsoil........... & 14.37 & .00 & .39 & 7.40 & 7.28 & 12.13 & 59.35 \\
\hline 332 & Soil............. & 14.37 & 1.15 & 1.61 & 18.34 & 16.28 & 23.88 & 25.37 \\
\hline 333 & & 14.05 & 1.02 & 1.28 & 20.63 & 17.88 & 22.11 & 24.06 \\
\hline \multirow[t]{2}{*}{334} & Soil.... & 15.23 & .62 & 1.63 & 15.33 & 15.77 & 21.73 & 31.61 \\
\hline & Waipio district. & & & & & & & \\
\hline \multirow[t]{2}{*}{114} & Hawaiian Pineapple Co. & 16.60 & .04 & 1.62 & 8.94 & 9.08 & 31.35 & 32.20 \\
\hline & Wahiawa district. & & & & & & & \\
\hline & Hawaiian Pineapple Co: & & & & & & & \\
\hline $\begin{array}{l}7 \\
9\end{array}$ & Soil $\mathrm{Do}, \ldots$ & 13.14 & .00 & $\begin{array}{r}.77 \\
8.20\end{array}$ & $\begin{array}{r}3.64 \\
22.44\end{array}$ & $\begin{array}{r}8.85 \\
3.94\end{array}$ & 34.54 & 36.28 \\
\hline 97 & & 14.32 & .09 & $\begin{array}{r}0.20 \\
.43\end{array}$ & $\begin{array}{r}22.44 \\
1.62\end{array}$ & $\begin{array}{r}10.94 \\
3.31\end{array}$ & $\begin{array}{l}27.15 \\
27.19\end{array}$ & $\begin{array}{l}13.11 \\
52.30\end{array}$ \\
\hline 98 & Do. & 13.6 & .12 & .43 & 2. & $\begin{array}{l}0.0 \\
3 .\end{array}$ & 26.32 & 55.05 \\
\hline 99 & D & 15.8 & .73 & .86 & 2. & 9. & 32. & 38.60 \\
\hline 101 & & 13.0 & .14 & .50 & 1.3 & 6. & 28. & 47.45 \\
\hline 102 & Do. & 14.6 & .29 & .91 & 1.1 & 7. & 18.87 & 57.80 \\
\hline 103 & & 17. & .05 & .26 & .8 & & 22.70 & 56.72 \\
\hline 104 & & 16.1 & .09 & .42 & 2.36 & 6. & & 44.54 \\
\hline 100 & Subsoil.... & 15.5 & .41 & 1.65 & 1.6 & 6. 72 & 18. 45 & 57.80 \\
\hline 530 & Soil........ & 14. & 0.5 & & 5. & 10.74 & & 28.95 \\
\hline 19 & Thomas Pineapple Co... & 13.3 & 0.6 & & 2.31 & 6.79 & 38.42 & 37.58 \\
\hline 15 & Hawaiian Preserving Co. & 16.66 & 2.54 & 6.28 & 21.17 & 14.57 & 21.90 & 15.50 \\
\hline 516 & Do...................... & 19.7 & 3.79 & 5.90 & 33.10 & $11.50^{\circ}$ & 17.56 & 8.42 \\
\hline 574 & & 15.1 & 1.24 & .39 & 8. & & 26.90 & 37.70 \\
\hline 542 & Kunia..... & 19.3 & 0.8 & & 33.95 & & 19.34 & 11.95 \\
\hline 282 & Leilehua................... & 20.34 & .69 & 2.31 & 23 . & 12.84 & 23. 69 & 18.45 \\
\hline 283 & Do $\ldots$ & 18.88 & .80 & 2.86 & 23. & 11. & 20.95 & 22.59 \\
\hline 284 & Do. & 21.20 & .69 & 2.41 & 28.11 & 11. 26 & 19.86 & 19.51 \\
\hline 285 & Do................. & 19. & .95 & 2.39 & 25. & 10.69 & 22.71 & 19.37 \\
\hline 286 & Do................ & 21.11 & .34 & 1.76 & 24.89 & 13.13 & 23.65 & 16.71 \\
\hline \multirow[t]{2}{*}{287} & Do....... & 20.48 & .91 & 1.80 & 27.47 & 11.13 & 22.96 & 17.90 \\
\hline & Waialua district. & & & & & & & \\
\hline & Helemano... & & & 1.65 & & 12.86 & 9.82 & 11.31 \\
\hline 164 & Opaeula................. & 3. 61 & 0.1 & & 3. 79 & 19.50 & 51.70 & 21.10 \\
\hline 115 & 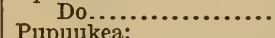 & 12.88 & & & 3.72 & 6.03 & 45.40 & 31.80 \\
\hline & $\begin{array}{l}\text { Pupuukea: } \\
\text { Soil }\end{array}$ & 14.54 & .02 & .42 & 11.65 & 11.41 & 46.30 & 16.77 \\
\hline 50 & Subsoil...... & 14.15 & .04 & .23 & 3. 88 & 6.67 & 28.43 & 48.57 \\
\hline 51 & Soil........ & 16. 39 & 1.98 & 3.67 & 19.57 & 9.16 & 32.09 & 19.13 \\
\hline 52 & Subsoil................... & 13.54 & 2.16 & 6.71 & 11.22 & 7.43 & 23.75 & 36.69 \\
\hline
\end{tabular}


TABLE III.-Mechanical composition of Hawaiian soils-Continued.

\begin{tabular}{|c|c|c|c|c|c|c|c|c|}
\hline $\begin{array}{l}\text { Soil } \\
\text { No. }\end{array}$ & Location. & $\begin{array}{l}\text { Volatile } \\
\text { matter. }\end{array}$ & $\begin{array}{c}\text { Fine } \\
\text { gravel. }\end{array}$ & $\begin{array}{l}\text { Coarse } \\
\text { sand. }\end{array}$ & $\begin{array}{l}\text { Fine } \\
\text { sand. }\end{array}$ & Silt. & Fine silt. & Clay. \\
\hline & ОАН U-Continued. & & & & & & & \\
\hline & Koolauloa district. & & & & & & & \\
\hline 347 & $\begin{array}{l}\text { Koluanui: } \\
\text { Sofl.... }\end{array}$ & $\begin{array}{r}\text { Per cent. } \\
36.14\end{array}$ & $\begin{array}{l}\text { Per cent. } \\
0.41\end{array}$ & $\begin{array}{r}\text { Per cent. } \\
0.83\end{array}$ & $\begin{array}{r}\text { Per cent. } \\
21.49\end{array}$ & $\begin{array}{r}\text { Per cent. } \\
27.45\end{array}$ & $\begin{array}{r}\text { Per cent. } \\
7.61\end{array}$ & $\begin{array}{l}\text { Percent. } \\
6.38\end{array}$ \\
\hline \multirow[t]{2}{*}{348} & Subsoil. & & & & 11. 29 & 15.27 & 20.07 & \\
\hline & Koolaupoko district. & & & & & & & \\
\hline & Waiahole: & & & & & & & \\
\hline $\begin{array}{l}345 \\
346\end{array}$ & Subsoil. & $\begin{array}{l}15.04 \\
15.31\end{array}$ & $\begin{array}{l}.15 \\
.46\end{array}$ & $\begin{array}{l}3.09 \\
3.59\end{array}$ & $\begin{array}{l}25.94 \\
34.44\end{array}$ & $\begin{array}{l}20.97 \\
19.30\end{array}$ & $\begin{array}{l}15.96 \\
10.96\end{array}$ & 19.84 \\
\hline 319 & Heeia......... & 20.31 & .11 & .54 & 20.98 & 18.07 & 25.31 & 16.42 \\
\hline \multirow{2}{*}{$\begin{array}{l}300 \\
301\end{array}$} & Soil... & 13.94 & .75 & .59 & 24.11 & 14.47 & 35.03 & 11.05 \\
\hline & $\begin{array}{l}\text { Subsoil........ Heeia: } \\
\text { Wireless Station, }\end{array}$ & 11.71 & .23 & .35 & 31.08 & 19.13 & 21.91 & 15.59 \\
\hline 302 & Soil ................ & 23.71 & .23 & .48 & 15.56 & 17.66 & 31.42 & 11.44 \\
\hline 303 & Subsoil.. & 16.43 & .22 & .23 & 5.93 & 9.42 & 25.72 & 42.78 \\
\hline \multirow{2}{*}{305} & Soil ..................... & 16.14 & .17 & .42 & 16.76 & 16.61 & 25.47 & 23.53 \\
\hline & $\begin{array}{l}\text { Subsoll.................... } \\
\text { Koeling's, Kaneohe: }\end{array}$ & 16.13 & .23 & .32 & 12.78 & 15.51 & 27.79 & 26.78 \\
\hline \multirow{2}{*}{$\begin{array}{l}300 \\
307\end{array}$} & Soil.................. & 17.34 & .22 & .35 & 10.50 & 13. 03 & 37.03 & 22.06 \\
\hline & $\begin{array}{l}\text { Subsoil............ } \\
\text { Kaneohe: }\end{array}$ & 19.44 & .17 & .53 & 26.64 & 16.17 & 28.53 & 8.76 \\
\hline 308 & Soil.................... & 19.12 & .96 & 1.10 & 17.57 & 14.00 & 35.86 & 10.72 \\
\hline 309 & Subsoil. & 18. 21 & .74 & .94 & 17.66 & 15. 97 & 36.36 & 10.90 \\
\hline 310 & Soil.... & 18. 53 & .19 & .54 & 13.40 & 19.08 & 29.24 & 20.07 \\
\hline 311 & Subsoil. & 17.81 & .26 & .62 & 10.41 & 15. 09 & 21.65 & 32.45 \\
\hline 312 & Soil.... & 22.42 & .21 & .96 & 25.76 & 13.54 & 25.19 & 14.74 \\
\hline 313 & Do. & 13.64 & .63 & 1.46 & 20.90 & 45. 63 & 11.38 & 8.34 \\
\hline 314 & Subsoil.. & 11. 95 & .35 & 1.00 & 24.68 & 26.08 & 27.35 & 7.55 \\
\hline 315 & Soil..... & 20.69 & .32 & 1.35 & 23.80 & 15.21 & 21.91 & 19.25 \\
\hline 316 & Subsoil.. & 17.77 & .33 & .87 & 23.79 & 20.87 & 17.34 & 20.04 \\
\hline 317 & Soil..... & 19.08 & .13 & .56 & 12.62 & 16.82 & 26.53 & 25.83 \\
\hline 318 & Subsoil.... & 19.30 & .09 & .75 & 16.14 & 22.17 & 24.82 & 18.17 \\
\hline 343 & Soil....... & 15.44 & .05 & .19 & 16.03 & 30.79 & 14.64 & 20.16 \\
\hline 344 & Subsoil... & 13.20 & .22 & .11 & 15.29 & 28.94 & 20.67 & 21.73 \\
\hline 337 & Soil.... & 18.72 & .35 & .69 & 18.78 & 13.57 & 22.92 & 25.70 \\
\hline 338 & Subsoil. & 19.54 & .33 & .86 & 18.60 & 15. 97 & 21.97 & 23.19 \\
\hline 339 & Soil....... & 21.17 & .13 & .22 & 18.13 & 20.42 & 22.37 & 19.19 \\
\hline 340 & Subsoil... & 19.41 & .06 & .31 & 16.75 & 19. 27 & 23.42 & 22.98 \\
\hline & Maunawili: & 1030 & & & & & & \\
\hline $\begin{array}{l}541 \\
342\end{array}$ & Subsoil... & 20.61 & .28 & 1.31 & 17.90 & $\begin{array}{l}20.92 \\
16.18\end{array}$ & $\begin{array}{l}15.04 \\
34.39\end{array}$ & $\begin{array}{l}12.20 \\
11.37\end{array}$ \\
\hline
\end{tabular}





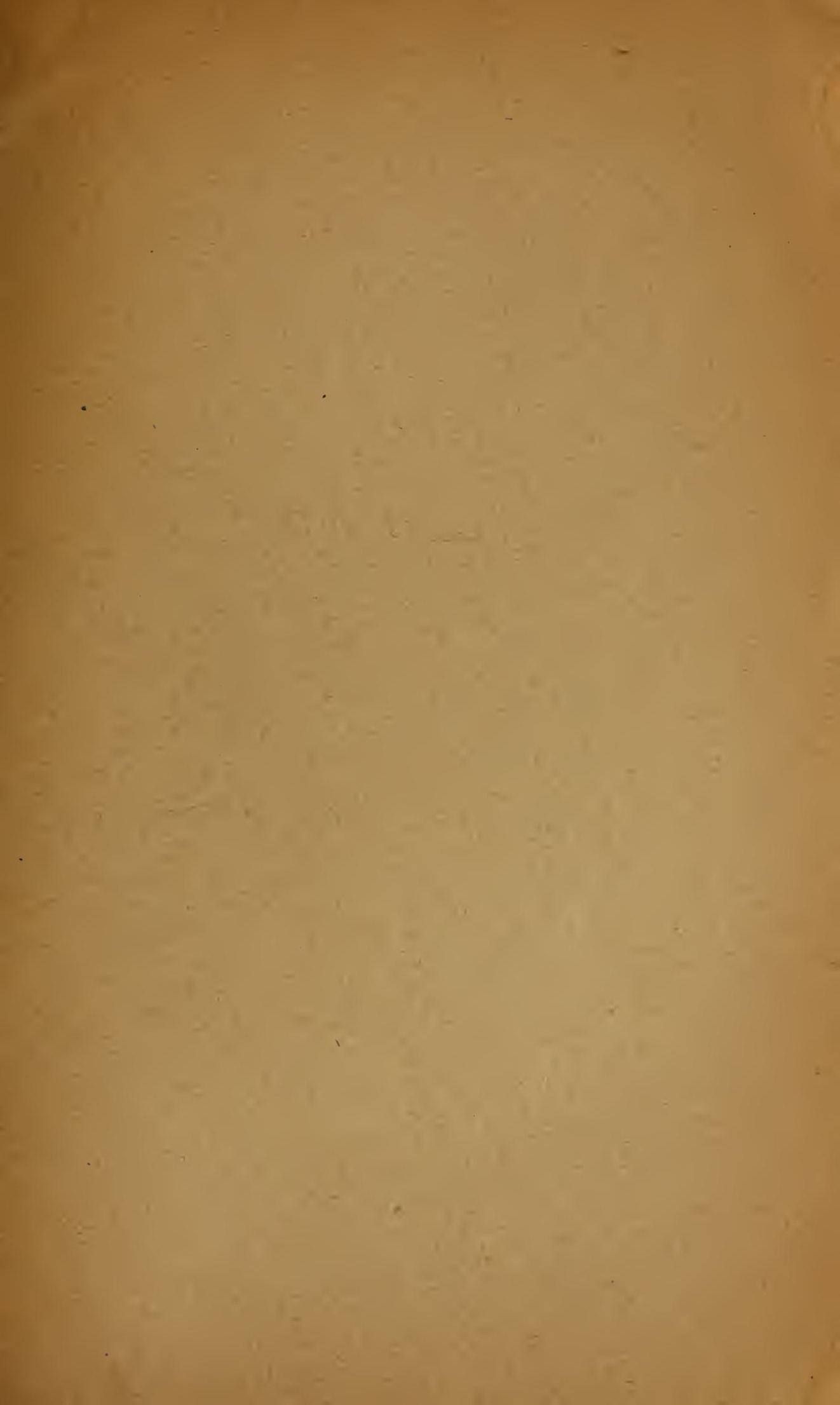


UNIVERSITY OF FLORIDA 